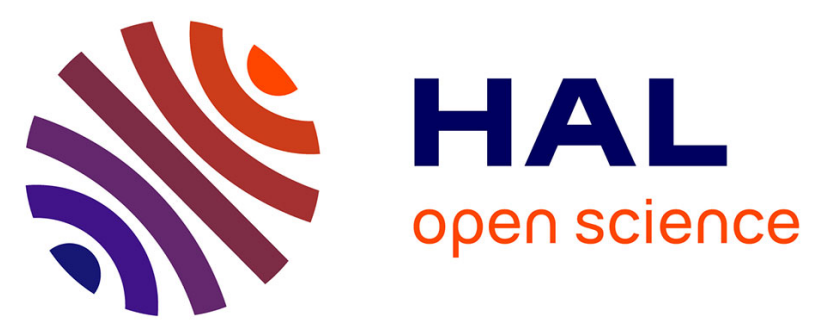

\title{
On the effect of yttrium promotion on Ni-layered double hydroxides-derived catalysts for hydrogenation of $\mathrm{CO} 2$ to methane
}

Chao Sun, Katarzyna Świrk, Dominik Wierzbicki, Monika Motak, Teresa Grzybek, Patrick da Costa

\section{To cite this version:}

Chao Sun, Katarzyna Świrk, Dominik Wierzbicki, Monika Motak, Teresa Grzybek, et al.. On the effect of yttrium promotion on Ni-layered double hydroxides-derived catalysts for hydrogenation of CO2 to methane. International Journal of Hydrogen Energy, 2021, 46 (22), pp.12169-12179. 10.1016/j.ijhydene.2020.03.202 . hal-03199460

\section{HAL Id: hal-03199460 https://hal.sorbonne-universite.fr/hal-03199460}

Submitted on 15 Apr 2021

HAL is a multi-disciplinary open access archive for the deposit and dissemination of scientific research documents, whether they are published or not. The documents may come from teaching and research institutions in France or abroad, or from public or private research centers.
L'archive ouverte pluridisciplinaire HAL, est destinée au dépôt et à la diffusion de documents scientifiques de niveau recherche, publiés ou non, émanant des établissements d'enseignement et de recherche français ou étrangers, des laboratoires publics ou privés. 


\title{
On the effect of yttrium promotion on Ni- layered double hydroxides-derived catalysts for hydrogenation of $\mathrm{CO}_{2}$ to methane
}

\author{
Chao Sun ${ }^{\mathrm{a}}$, Katarzyna Świrk ${ }^{\mathrm{a}, \mathrm{b}}$, Dominik Wierzbicki ${ }^{\mathrm{a}, \mathrm{b}}$, Monika Motak ${ }^{\mathrm{b}}$, Teresa Grzybek ${ }^{\mathrm{b}}$, \\ $\underline{\text { Patrick Da Costa }}^{\text {a,* }}$ \\ a Sorbonne Université, CNRS UMR 7190, Institut Jean Le Rond d'Alembert, 2 Place de la Gare de \\ Ceinture, 78210 Saint-Cyr-L'École, France \\ ${ }^{\mathrm{b}}$ AGH University of Science and Technology, Faculty of Energy and Fuels, Al. A. Mickiewicza 30, \\ 30-059 Cracow, Poland \\ * patrick.da_costa@sorbonne-universite.fr; chao.sun@dalembert.upmc.fr
}

\begin{abstract}
:
Ni-containing mixed oxides derived from layered double hydroxides with various amounts of yttrium were synthesized by a co-precipitation method at constant $\mathrm{pH}$ and then obtained by thermal decomposition. The characterization techniques of $\mathrm{XRD}$, elemental analysis, low-temperature $\mathrm{N}_{2}$ sorption, $\mathrm{H}_{2}-\mathrm{TPR}, \mathrm{CO}_{2}-\mathrm{TPD}$, TGA and TPO were used on the studied catalysts. The catalytic activity of the catalysts was evaluated in the $\mathrm{CO}_{2}$ methanation reaction performed at atmospheric pressure. The obtained results confirmed the formation of nano-sized mixed oxides after the thermal decomposition of hydrotalcites. The introduction of yttrium to $\mathrm{Ni} / \mathrm{Mg} / \mathrm{Al}$ layered double hydroxides led to a stronger interaction between nickel species and the matrix support and decreased nickel particle size as compared to the yttrium-free catalyst. The modification with $\mathrm{Y}(0.4$ and 2 wt.\% $)$ had a positive effect on the catalytic performance in the moderate temperature region $\left(250-300{ }^{\circ} \mathrm{C}\right)$, with $\mathrm{CO}_{2}$ conversion
\end{abstract}


increasing from $16 \%$ for MO-0Y to $81 \%$ and $40 \%$ for MO- $0.4 \mathrm{Y}$ and MO-2.0Y at $250{ }^{\circ} \mathrm{C}$, respectively. The improved activity may be correlated with the increase of percentage of medium-strength basic sites, the stronger metal-support interaction, as well as decreased crystallite size of metallic nickel. High selectivity towards methane of $99 \%$ formation at $250{ }^{\circ} \mathrm{C}$ was registered for all the catalysts.

Keywords: $\mathrm{CO}_{2}$ methanation, hydrotalcite, mixed oxides, yttrium, nickel catalyst

\section{Introduction}

The reduction of $\mathrm{CO}_{2}$ emissions has gained legislative importance as it is considered one of the major drivers of climate change [1]. The reduction of carbon dioxide emissions is becoming attractive because of the cost of carbon feedstock [2]. $\mathrm{CO}_{2}$ hydrogenation into methane over transition metal-based catalysts using renewable hydrogen from water electrolysis as an example has a huge potential to reduce the emissions and, at the same time, to store the excess renewable energy to equalize the demand and capacity in a power to gas process [3-5]. Due to the lack of costly infrastructure for the distribution and storage of hydrogen, $\mathrm{CO}_{2}$ hydrogenation seems to be a promising alternative approach [6,7]. Additionally, methane can be easily liquefied and stored in the existing infrastructure [7]. Out of all proposed $\mathrm{CO}_{2}$ hydrogenation reactions, e.g., methanol synthesis, higher hydrocarbons or methanation, the most developed one methanation $\left(\mathrm{CO}_{2}+4 \mathrm{H}_{2}=\mathrm{CH}_{4}+2 \mathrm{H}_{2} \mathrm{O}\right)$, with a few plants already operational in European Union [8,9]. 
The most widely studied catalysts for Sabatier's reaction in literatures are those based on group 8, 9, 10 metals-Fe, $\mathrm{Ru}, \mathrm{Rh}, \mathrm{Co}, \mathrm{Ni}$, or Pt [3,6,10-22]. However, the most active and selective catalysts towards methane were found to be those based on Rh, Ru and Ni $[6,9,10,19,22-24]$. Nickel-based catalysts have the advantage over noble metal-based catalysts because of their low cost, high availability and accessibility[7,25-28].

Layered double hydroxides (LDH) or hydrotalcite (HT) are materials with di- and tri-valent cations incorporated into the brucite-like layers. The layers of hydrotalcites are positively charged, and anions present in the interlayer spaces are compensating the charge. It was reported in the literature that there is a wide range of cations that maybe incorporated into the hydrotalcites structure, e.g., $\mathrm{Li}^{+}, \mathrm{Ti}^{4+}, \mathrm{Sn}^{4+}$ or $\mathrm{Zr}^{4+}$ [29]. Calcination of such materials leads to the formation of mixed nano-oxides with periclase-like structure, which show very interesting features [7,30-34]. Redox or acid-base properties of such materials may be tailored to some extent by controlling hydrotalcite composition, as shown e.g. in $\mathrm{NH}_{3}$-SCR [35-39] or DRM [40-45] reactions. Another advantage of double layered hydroxides is that the incorporated cations are usually homogenously distributed due to their random arrangement in the brucite-like layers. Moreover, such materials exhibit basic properties, which are of great interest when used as catalysts for the reaction of $\mathrm{CO}_{2}$ methanation $[35,44,46-51]$

Several aspects were already investigated in case of hydrotalcite-derived catalysts for $\mathrm{CO}_{2}$ methanation reaction such as (i) the effect of nickel content, (ii) the particle 
size of nickel crystallites, (iii) the reducibility of nickel species, (iv) the number and distribution of basic sites, and (v) the promotion with other metals such as $\mathrm{La}$, Fe, etc. or the new preparation method[46,49,52-56].

Fan et al. [57] studied $\mathrm{Ni}$ impregnated $\mathrm{MgAl}_{2} \mathrm{O}_{4}$ derived from hydrotalcite followed by calcination at $500{ }^{\circ} \mathrm{C}$ or treated by DBD plasma in order to decompose Ni precursor. The plasma treatment resulted in higher nickel dispersion of $7.1 \%$ for plasma decomposition method prepared sample, compared to $6.0 \%$ for the traditionally calcined material. The authors claimed that smaller metallic nickel particles resulted in enhanced activity in the reaction of $\mathrm{CO}_{2}$ methanation. Wang et al. [55] studied Ni/Al HTs promoted with 0.05 and $0.25 \%$ molar ratio of $\mathrm{Fe}$ and found that the introduction of $\mathrm{Fe}$ effectively enhanced the $\mathrm{H}_{2}$ adsorption capacity. $\mathrm{Ni} / \mathrm{Mg} / \mathrm{Al}$ hydrotalcites promoted with a wide range of $\mathrm{Fe}$ content $(1.2-18$ wt.\% of $\mathrm{Fe})$ were examined by Mebrahtu et al. [58]. It was found that the activity in $\mathrm{CO}_{2}$ methanation was effectively increased in the low temperature region when low amounts of iron were introduced. In our previous reports, we investigated the influence of Ni loading and the effect of La introduction on the catalytic activity of LDHs catalysts in $\mathrm{CO}_{2}$ methanation $[46,49,50]$. The incorporation of higher amounts of nickel, as well as introduction of lanthanum, significantly enhanced the activity in $\mathrm{CO}_{2}$ methanation reaction. This could be correlated with the increased number of medium-strength basic sites, which in case of La-promoted catalysts was strongly dependent on the method of promoter introduction [49][59][60]. According to the study of Pan et al. [60] 
$\mathrm{CO}_{2}$ adsorbed on $\mathrm{Ni} / \mathrm{Ce}_{0.5} \mathrm{Zr}_{0.5} \mathrm{O}_{2}$ may undergo hydrogenation easier than on $\mathrm{Ni} / \mathrm{Al}_{2} \mathrm{O}_{3}$ because of the higher content of medium basic sites.

Yttrium had been reported in the literature as a promising dopant in methane dry reforming reaction $\left(\mathrm{CO}_{2}+\mathrm{CH}_{4}=2 \mathrm{H}_{2}+2 \mathrm{CO}\right)[44,47,61-66]$. The increased activity of the Ni-containing hyrotalcites was attributed to the enhanced dispersion of the active phase in comparison with the un-promoted materials $[44,47,64]$. The stability of the $\mathrm{Zr}$ - containing catalysts in DRM reaction was also enhanced by the introduction of $\mathrm{Y}$, which was assigned to the formation of a solid-solution $\mathrm{ZrO}_{2}-\mathrm{Y}_{2} \mathrm{O}_{3}$, leading to the increased reducibility of bulk $\mathrm{NiO}$ [45]. Moreover, Bellido et al. [67] reported that ceria doped with yttrium showed enhanced oxygen mobility and oxygen vacancies. For $\mathrm{CO}_{2}$ methanation, Muroyama et al. [68] reported that $\mathrm{Y}_{2} \mathrm{O}_{3}$ impregnated with $\mathrm{Ni}$ revealed very high activity in the low-temperature region in $\mathrm{CO}_{2}$ methanation when compared to $\mathrm{Ni}$ supported on $\mathrm{Al}_{2} \mathrm{O}_{3}, \mathrm{ZrO}_{2}$ and $\mathrm{CeO}_{2}$ catalysts. It was attributed to the promoted decomposition of formate species formed during the reaction over $\mathrm{Ni} / \mathrm{Y}_{2} \mathrm{O}_{3}$ catalysts.

To the best of our knowledge, there are no literature reports regarding yttrium promoted $\mathrm{Ni}$-containing hydrotalcite-derived catalysts for $\mathrm{CO}_{2}$ hydrogenation to methane. Our study was focused on the determination of the influence of $\mathrm{Y}$ introduction to $\mathrm{Ni}$-containing layered double hydroxides on the catalytic performance in $\mathrm{CO}_{2}$ methanation. The catalysts were synthesized using the co-precipitation method at a constant $\mathrm{pH}$ and with a fixed molar ratio of $\mathrm{M}^{\mathrm{II}+} / \mathrm{M}^{\mathrm{III+}}=3.0$. The assumed loading of yttrium introduced into hydrotalcite was $0.4,2.0$ and $4.0 \mathrm{wt} . \%$. To correlate the 
changes in activity with the Physico-chemical properties, the studied materials were characterized using various techniques such as X-ray diffraction (XRD), low-temperature $\mathrm{N}_{2}$ sorption, $\mathrm{X}$-ray fluorescence (XRF), temperature-programmed reduction in $\mathrm{H}_{2}\left(\mathrm{H}_{2}-\mathrm{TPR}\right)$, temperature-programmed desorption of $\mathrm{CO}_{2}\left(\mathrm{CO}_{2}-\mathrm{TPD}\right)$, thermogravimetric analysis (TGA) and temperature-programmed oxidation (TPO).

\section{Experimental}

\subsection{Catalysts preparation}

The co-precipitation method with sodium carbonate was carried out for catalyst preparation. An aqueous solution of following nitrates was used: $\mathrm{Ni}, \mathrm{Y}, \mathrm{Al}$, and $\mathrm{Mg}$, and added dropwise into $\mathrm{Na}_{2} \mathrm{CO}_{3}$ solution. $\mathrm{NaOH}(2 \mathrm{M})$ was also dripped into the

mixture to adjust $\mathrm{pH}$ to $10 \pm 0.2$. The ratio of $\mathrm{M}^{2+} / \mathrm{M}^{3+}$ was assumed as 3 . The assumed loading of yttrium was $0.4 \mathrm{wt} . \%, 2.0 \mathrm{wt} . \%$ or $4.0 \mathrm{wt} . \%$. After co-precipitation, the slurry was left to react at $65^{\circ} \mathrm{C}$ for $24 \mathrm{~h}$. Then, this mixture was filtered under vacuum and washed with distilled water. After filtration, the obtained cake was dried at $80{ }^{\circ} \mathrm{C}$ overnight and calcined in static air at $550{ }^{\circ} \mathrm{C}$ for $5 \mathrm{~h}$ with a ramp of $5{ }^{\circ} \mathrm{C} / \mathrm{min}$. The samples were designated as MO-0Y, MO-0.4Y, MO-2.0Y, and MO-4.0Y.

\subsection{Catalysts characterization}

\subsubsection{Elemental composition, structural parameters, and textural properties}

X-Ray Fluorescence (XRF) using a Rigaku Supermini200 analyzer to evaluate the elemental analysis of the studied catalysts. The experiment was performed under 
vacuum at $36.5{ }^{\circ} \mathrm{C}$ in the presence of $\mathrm{P}-10$ gas (a mixture of $10 \% \mathrm{CH}_{4} / \mathrm{Ar}$, flow 24.7 $\mathrm{mL} / \mathrm{min}$ ). A pulse height analyzer was used to calibrate the proportional counter (PC) detector. The calcined sample was homogeneously mixed with boric acid and pelletized under 10 bar. So prepared pellet was then covered by polypropylene film (6 $\mu \mathrm{m})$ and put into a sample holder for the analysis.

The structural properties of the reduced and spent catalysts were studied by X-ray diffraction (XRD). XRD patterns were collected on a PANalytical-Empyrean diffractometer, equipped with a copper-based anode $(\mathrm{Cu}-\mathrm{K} \alpha, \lambda=0.154059 \mathrm{~nm})$. The instrument settings were $40 \mathrm{~mA}$ and $45 \mathrm{kV}$. For the evaluation of $\mathrm{Ni}^{0}$ (metallic nickel) particle size, the Scherrer equation was used.

Low-temperature $\mathrm{N}_{2}$ adsorption-desorption method was conducted in a TriStar II 3020 (Micromeritics) apparatus for the study of the textural properties of the catalysts. Before the measurement, $100 \mathrm{mg}$ of the sample was degassed at $110^{\circ} \mathrm{C}$ for $3 \mathrm{~h}$. Then the measurement was carried out at liquid nitrogen temperature $\left(-196{ }^{\circ} \mathrm{C}\right)$. The specific surface area of the sample was calculated by the Brunauer-Emmett-Teller (BET) method, and the mesopore volume and average pore diameter by the Barrett-Joyner-Halenda (BJH) desorption method.

\subsubsection{Temperature programmed reduction in $\mathbf{H}_{2}$}

The reducibility of the hydrotalcite-derived mixed-oxide was measured by temperature-programmed reduction of $\mathrm{H}_{2}\left(\mathrm{H}_{2}\right.$-TPR) method, using a BELCAT-M apparatus (BEL Japan Inc.) equipped with a thermal conductivity detector (TCD). 60 
$\mathrm{mg}$ of sample was previously degassed in a flow of helium $(99.999 \% \mathrm{He}, 50 \mathrm{~mL} / \mathrm{min})$ at $100{ }^{\circ} \mathrm{C}$ for $2 \mathrm{~h}$ to eliminate impurities, then the sample was reduced from $100{ }^{\circ} \mathrm{C}$ to $900{ }^{\circ} \mathrm{C}$ with the temperature ramp of $10{ }^{\circ} \mathrm{C} / \mathrm{min}$ in a $5 \% \mathrm{H}_{2} / \mathrm{Ar}$ gas mixture $(50$ $\mathrm{mL} / \mathrm{min})$.

\subsubsection{Temperature programmed desorption of $\mathrm{CO}_{2}$}

The number and distribution of basic sites were determined by temperature-programmed desorption of $\mathrm{CO}_{2}$, measured in the same equipment as $\mathrm{H}_{2}$-TPR. After the TPR experiment, the sample was cooled down to $80{ }^{\circ} \mathrm{C}$ for the TPD test. The sample was pretreated using a flow of pure helium $(50 \mathrm{~mL} / \mathrm{min})$ at $80{ }^{\circ} \mathrm{C}$ for $2 \mathrm{~h}$, and then $\mathrm{CO}_{2}$ was adsorbed from $10 \% \mathrm{CO}_{2} / \mathrm{He}$ mixture $(50 \mathrm{~mL} / \mathrm{min})$ for $1 \mathrm{~h}$. Then, the catalyst was cleaned by pure helium for 15 min to desorb weakly physically adsorbed $\mathrm{CO}_{2}$. Afterward, the catalyst was heated from $80{ }^{\circ} \mathrm{C}$ to $800{ }^{\circ} \mathrm{C}$ in $\mathrm{He}(50$ $\mathrm{mL} / \mathrm{min}$ ) with a heating rate of $10^{\circ} \mathrm{C} / \mathrm{min}$. The obtained profiles were deconvoluted and integrated as presented elsewhere [8,9].

\subsubsection{Thermogravimetric analyses (TGA)}

Thermogravimetric analysis was performed on the spent catalysts by the Q5000 IR apparatus. Around $25 \mathrm{mg}$ of material was heated starting from room temperature to $750{ }^{\circ} \mathrm{C}$ (heating rate of $10{ }^{\circ} \mathrm{C} / \mathrm{min}$ ). The measurements were performed in synthetic air. The amount of $\mathrm{H}_{2} \mathrm{O}$ and adsorbed $\mathrm{CO}_{2}$ were estimated by the mass loss registered in the TGA plots. 


\subsubsection{Temperature-programmed oxidation (TPO)}

The TPO analyses were carried out on the spent catalysts by Quadstar Mass equipped with a Pfeiffer Vacuum. Around $30 \mathrm{mg}$ of a sample was heated from ambient temperature to $800{ }^{\circ} \mathrm{C}$ with a heating rate of $5{ }^{\circ} \mathrm{C} / \mathrm{min}$. The measurements were performed in $5 \% \mathrm{O}_{2} / \mathrm{Ar}$ gas of $200 \mathrm{ml} / \mathrm{min}$ (Volumetric percentage). During the mass spectroscopy analysis, the following desorbed species were recorded; m/z: 44 $\left(\mathrm{CO}_{2}\right)$ and $18\left(\mathrm{H}_{2} \mathrm{O}\right)$. The $\mathrm{CO}_{2}$ signal in the graph was enlarged 10 times for the analysis.

\subsection{Catalytic performance tests}

The catalytic tests of $\mathrm{CO}_{2}$ methanation were performed in a fixed-bed flow reactor (inner diameter: $8 \mathrm{~mm}$ ) under atmospheric pressure. The temperature in the catalytic bed was monitored using a K-type thermocouple, which was placed close to the catalyst bed. Before the tests, the calcined materials were reduced in situ from room temperature to $900{ }^{\circ} \mathrm{C}$ with a heating rate of $5{ }^{\circ} \mathrm{C} / \mathrm{min}$ under reduction gas $\left(5 \% \mathrm{H}_{2} / \mathrm{Ar}: 100 \mathrm{ml} / \mathrm{min}\right)$ and kept $1 \mathrm{~h}$ at $900{ }^{\circ} \mathrm{C}$. The reduction temperature was $900{ }^{\circ} \mathrm{C}$ because the nickel species could be reduced thoroughly at $900{ }^{\circ} \mathrm{C}$ according to the TPR result, which was also used in other literature [49]. After the reduction, the reactor was cooled down to $200^{\circ} \mathrm{C}$ and the reaction mixture was introduced with a molar ratio of $\mathrm{Ar} / \mathrm{H}_{2} / \mathrm{CO}_{2}=25 / 60 / 15$ and the GHSV of $12,000 \mathrm{~h}^{-1}$. The methanation tests were performed in the temperature range from 200 to $400{ }^{\circ} \mathrm{C}$ with a temperature 
step of $50{ }^{\circ} \mathrm{C}$, which are appropriate conditions for Ni-containing mixed oxides, as reported in many literatures $[49,59]$. At each plateau of temperature, the catalyst was kept for $30 \mathrm{~min}$, corresponding to a steady-state measurement. The flow rates of inlet and outlet were measured by flowmeter at each temperature when the reaction was stable. And the measured flow rates and the compositions obtained from GC were used to calculate the $\mathrm{CO}_{2}$ conversion $\left(\mathrm{X}_{\mathrm{CO} 2}\right)$ and $\mathrm{CH}_{4}$ selectivity $\left(\mathrm{S}_{\mathrm{CH} 4}\right)$.

$\mathrm{CO}_{2}$ conversion $\left(\mathrm{X}_{\mathrm{CO} 2}\right)$ and $\mathrm{CH}_{4}$ selectivity $\left(\mathrm{S}_{\mathrm{CH} 4}\right)$ are defined as:

\begin{tabular}{|c|c|c|}
\hline Conversion of $\mathrm{CO}_{2}=\mathrm{X}_{\mathrm{CO} 2}$ & $\frac{[\mathrm{CO} 2] \text { in }-[\mathrm{CO} 2] \text { out }}{[\mathrm{CO} 2] \text { in }}$ & $=\frac{\% \text { CO2in.Qin }-\% \text { CO2out.Qout }}{\% \text { CO2in.Qin }}$ \\
\hline Selectivity of $\mathrm{CH}_{4}=\mathrm{S}_{\mathrm{CH} 4}$ & $\frac{[\mathrm{CH} 4] \text { out }}{[\mathrm{CO}] \mathrm{in}-[\mathrm{CO} 2] \text { out }}$ & $=\frac{\% \text { CH4out.Qout }}{\% \text { CO2in.Qin-\%CO2out.Qout }}$ \\
\hline
\end{tabular}

In which Q is the flow rate ("in" for inlet, "out" for outlet).

\section{Results and discussion}

\subsection{Characterization of the catalysts before methanation}

3.1.1. Structural parameters, elemental composition, and textural properties of nano-mixed oxides derived from hydrotalcite

Structural parameters calculated from the XRD diffractograms acquired for as-synthesized materials are reported in Table 1. The structural parameters $\boldsymbol{a}$ and $\boldsymbol{c}$ were obtained by the equations of $a=2 d_{(110)}$ and $c=d_{(003)}+2 d_{(006)}+3 d_{(009)}$. The crystallographic parameter $\boldsymbol{a}\left(2 \mathrm{~d}_{110}\right)$ is associated with the average cation-cation distance in the hydroxide layers [33]. The parameter $\boldsymbol{a}$ is stable for all materials (3.06 Å), indicating the lack of possible distortions of the lattice. As stated by García-García 
et al. [69], yttrium can be incorporated into layers of double-layered hydroxides, though its ionic radius is somewhat larger than that of $\mathrm{Al}$ and $\mathrm{Mg}\left(\mathrm{Mg}^{3+}=0.86 \AA\right.$,

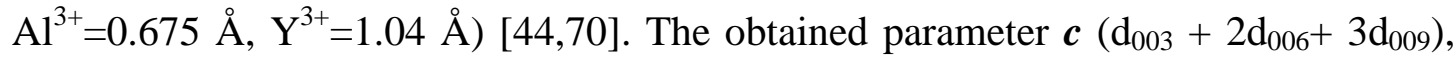
which refers to the triple thickness between brucite layers in hydrotalcite structure, decreased for low $\mathrm{Y}$ (under 2 wt.\%) modified samples in comparison to the non-modified material, except for MO-4.0Y, which increased to $23.51 \AA$ (Table 1). For the MO-4.0Y, some deposition of Yttrium on the external surface may be assumed. Moreover, the distance between the brucite-like layers $\left(c^{\prime}=\boldsymbol{c} / 3\right)$ is in the range of 7.79-7.84 $\AA$, showing the presence of interlayer anions, such as e.g. $\mathrm{CO}_{3}{ }^{2-}(7.65 \AA)$ and $\mathrm{NO}_{3}^{-}(8.79 \AA)$ [71-73]. The structural parameters revealed that the yttrium loading up to 2.0 wt. $\%$ could result in the introduction of this metal into the periclase-like structure. However, the higher content of the yttrium led to the increase of the interlayer space, which was possibly linked with the deposition of the metal on the surface of the layers. This agrees with the textural properties, as the specific surface area of MO-4.0Y significantly decreased compared with that of MO-2.0Y due to their partial blockage.

The elemental composition of nano-mixed oxides obtained by calcination acquired from the XRF method is presented in Table 1. All samples revealed nickel content between 16 and $20 \mathrm{wt} \%$, whereas the content of yttrium was either the same (MO-0.4Y) or close to the nominal amount (MO-2.0Y and MO-4.0Y). According to Li et al. [66], $\mathrm{Ni}^{2+}$ can be substituted by $\mathrm{Y}^{3+}$, similarly as observed in our study (Table 1). The calculated $\mathrm{M}^{2+} / \mathrm{M}^{3+}$ atomic ratios were fairly close to those assumed during 
the materials synthesis, indicating that the composition of LDHs may be easily controlled as reported before [74].

Table 1 Structural parameters (XRD), elemental composition (XRF) and textural properties (BET analysis) of yttrium modified nano-mixed oxides derived from hydrotalcite. Additionally, the nominal values are reported in brackets.

\begin{tabular}{|c|c|c|c|c|c|c|c|c|}
\hline \multirow[t]{2}{*}{ Catalyst } & \multicolumn{2}{|c|}{$\begin{array}{l}\text { Structural } \\
\text { parameters }\end{array}$} & \multicolumn{3}{|c|}{$\begin{array}{l}\text { Elemental composition of the calcined } \\
\text { materials }\end{array}$} & \multicolumn{3}{|c|}{$\begin{array}{l}\text { Textural properties of the } \\
\text { calcined materials }\end{array}$} \\
\hline & {$[\stackrel{\mathrm{a}}{[\AA}]^{\mathrm{a})}$} & $\begin{array}{c}\mathrm{c} \\
{[\AA]^{\mathrm{b})}}\end{array}$ & Ni [wt.\%] & $\mathrm{Y}[\mathrm{wt} . \%]$ & $\mathrm{M}^{2+} / \mathrm{M}^{3+}[-]$ & $\begin{array}{c}\mathrm{S}_{\mathrm{BET}} \\
2 \\
{[\mathrm{~m} / \mathrm{g}]} \\
\mathrm{c})\end{array}$ & $\begin{array}{c}\mathrm{V}_{\mathrm{p}} \\
\stackrel{3}{3} \\
{\left[\mathrm{~cm}_{\mathrm{d})} / \mathrm{g}\right]}\end{array}$ & $\begin{array}{c}\mathrm{d}_{\mathrm{p}} \\
{[\mathrm{nm}]}\end{array}$ \\
\hline MO-0Y & 3.06 & 23.45 & 20 & - & $3.6(3.0)$ & 120 & 0.6 & 19 \\
\hline MO-0.4Y & 3.06 & 23.38 & 21 & $0.4(0.4)$ & $3.5(3.0)$ & 120 & 0.5 & 15 \\
\hline MO-2.0Y & 3.06 & 23.42 & 18 & $1.8(2.0)$ & $3.4(3.0)$ & 192 & 0.6 & 14 \\
\hline MO-4.0Y & 3.06 & 23.51 & 16 & $3.4(4.0)$ & $3.7(3.0)$ & 153 & 0.7 & 18 \\
\hline \multicolumn{9}{|c|}{ a) calculated from d-spacing of (110) plane; $\mathrm{a}=2 \mathrm{~d}_{110}$} \\
\hline \multicolumn{9}{|c|}{ b) calculated from appropriate $d$-spacings of (003), (006) and (009) planes; $c=d_{003}+2 d_{006}+3 d_{009}$} \\
\hline \multicolumn{9}{|c|}{${ }^{c)}$ specific surface areas calculated from the BET equation } \\
\hline \multicolumn{9}{|c|}{ d) mesopore volumes obtained from the BJH desorption calculation method } \\
\hline
\end{tabular}

The textural parameters obtained from the $\mathrm{N}_{2}$ sorption isotherms for the calcined materials are listed in Table 1. All values agree with those previously reported in the literature $[35,44,45,47,49,50,54,59,64,73]$. The obtained specific surface areas ranged between 120 and $192 \mathrm{~m}^{2} \cdot \mathrm{g}^{-1}$ and the highest area was found for the MO-2.0Y catalyst. There are no significant difference regarding to BET surface area and pore volume of Ni-containing double-layered hydroxides-derived catalyst when the loading of yttrium is low $(\leq 0.4 \%)$ compared with Y-free sample, only the average pore size decreases as 
the increase of yttrium at low loading of yttrium [44,47]. As described in the section before, the structural parameters showed that the yttrium loading up to $2.0 \mathrm{wt} . \%$ could result in the introduction of this metal into the periclase-like structure. However, the higher content of the yttrium increased the interlayer space, which was possibly linked with the deposition of the metal on the outer surface of the layers. This agrees with the textural properties, as the specific surface area of MO-4.0 Y significantly decreased due to their partial blockage. The volume of mesopores did not change significantly after yttrium promotion. However, pore diameters diminished for MO-0.4Y and MO-2.0Y catalysts, as compared to the non-promoted material, pointing to the formation of a higher number of smaller pores when yttrium was introduced into the brucite-like layers.

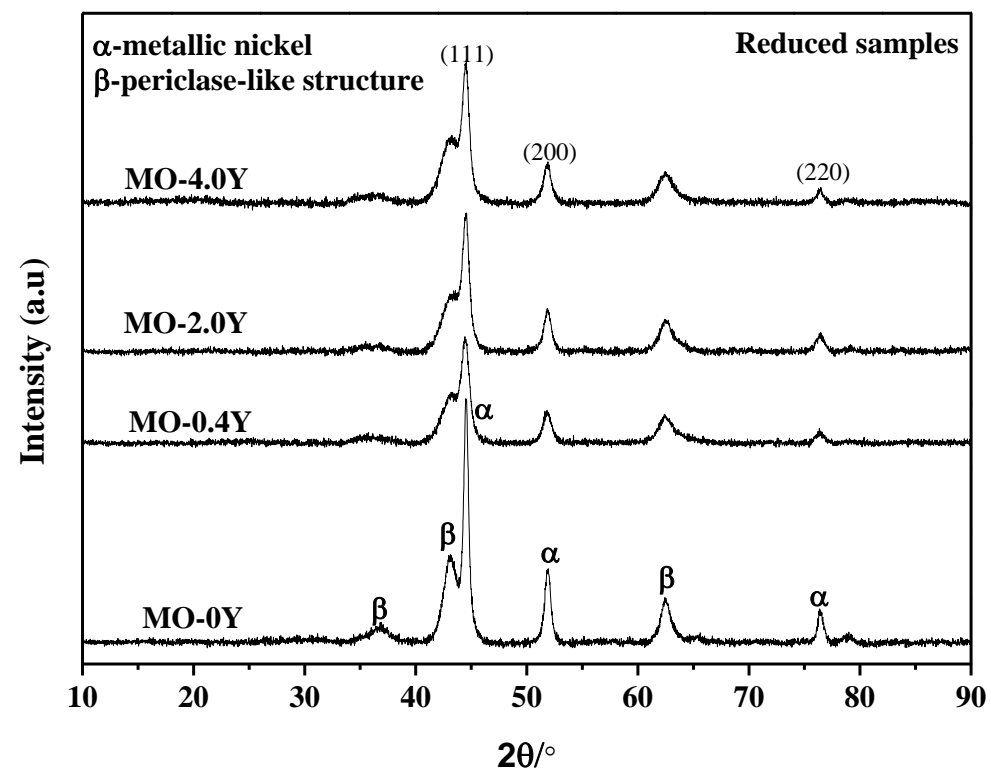

Fig. 1. XRD profiles for reduced nano-mixed oxides modified with different yttrium loadings 
$(0.4,2.0$, or $4.0 \mathrm{wt} . \%)$ and compared to the un-promoted catalyst (MO-0Y).

Fig. 1 shows XRD diffractograms of the reduced catalysts, in which metallic nickel phase (ICOD 01-087-0712) is evidenced by the presence of reflections at $2 \theta$ ca. 44.5, 53 and $76.5^{\circ}$, corresponding to crystal planes of (111), (200) and (220), respectively. Moreover, reflections arising from the periclase-like structure at $2 \theta$ ca. $36.7,43$ and $62.5^{\circ}$ are observed, which corresponds to mixed oxides obtained after thermal treatment of double-layered hydroxides $[44,45,47]$. Table 2 reports the size of $\mathrm{Ni}^{0}$ crystallites, calculated from the $2 \theta$ diffraction peak at ca. $52^{\circ}$ (corresponding to (200) crystal plane of $\mathrm{Ni}^{0}$ ) using the Scherrer equation. The yttrium promotion resulted in a decrease of nickel crystallites size from ca. $13.7 \mathrm{~nm}$ for the parent $\mathrm{MO}$ to ca. $9.2 \mathrm{~nm}$ for MO-0.4Y. The values obtained for MO-2.0Y and MO-4.0Y catalysts were close to the one registered for the unpromoted catalyst, i.e. 12.5 and $12.3 \mathrm{~nm}$, respectively.

Table $2 \mathrm{Ni}^{0}$ crystallite size for the reduced and spent materials calculated from XRD

\begin{tabular}{|c|c|c|}
\hline \multirow[t]{2}{*}{ Catalyst } & \multicolumn{2}{|c|}{$\mathrm{Ni}^{0}$ crystallite size } \\
\hline & Reduced samples [nm] ${ }^{\text {a) }}$ & Spent samples $[\mathrm{nm}]^{\mathrm{a}}$ \\
\hline MO-0Y & 13.7 & 9.3 \\
\hline MO-0.4Y & 9.2 & 7.9 \\
\hline MO-2.0Y & 12.5 & 7.6 \\
\hline MO-4.0Y & 12.3 & 7.5 \\
\hline
\end{tabular}

a) Calculated from the Scherrer equation at $2 \theta=52^{\circ}$ 


\subsubsection{Reducibility of catalysts followed by $\mathrm{H}_{2}$-TPR}

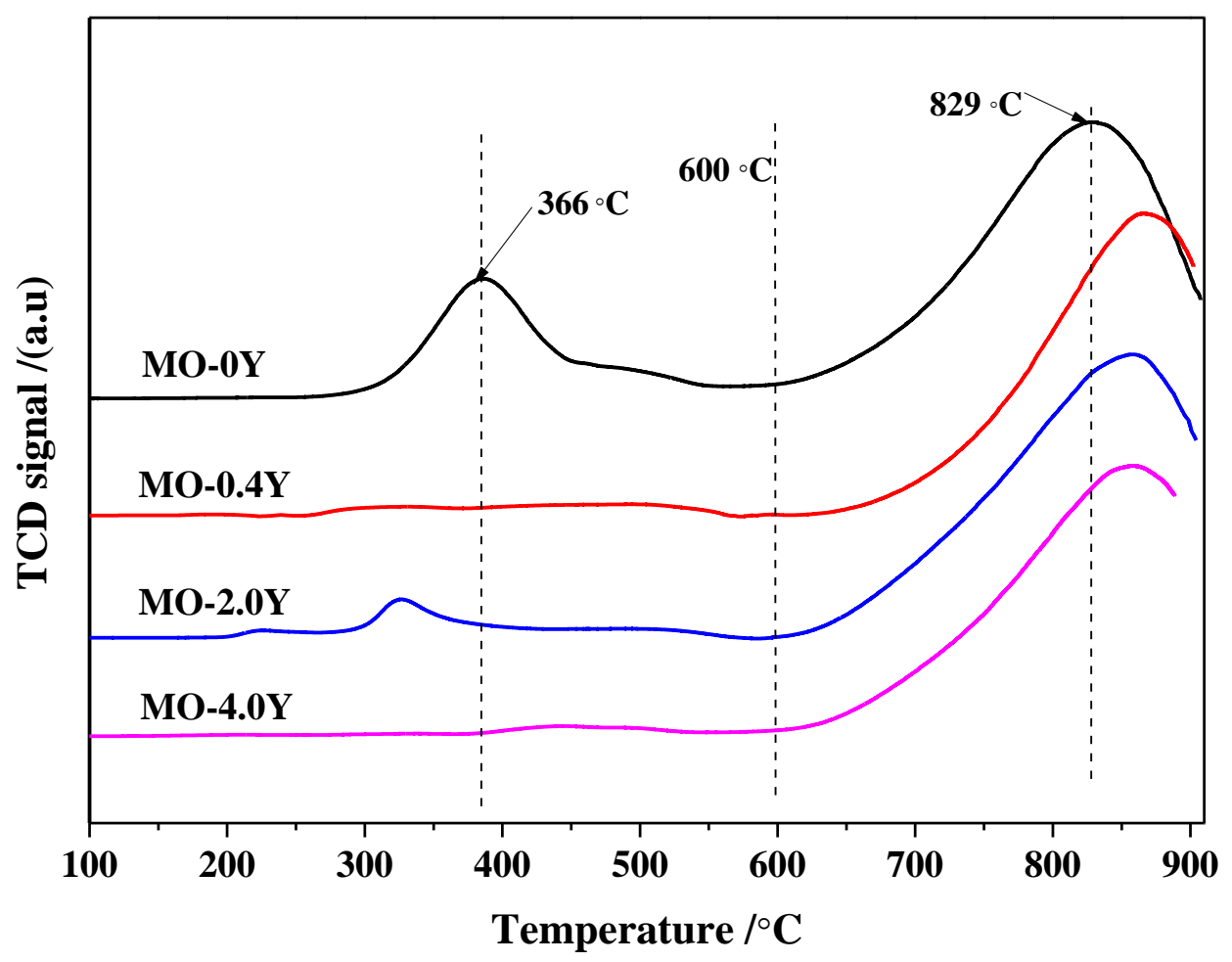

Fig. 2. $\mathrm{H}_{2}$-TPR profiles for mixed oxides modified with different yttrium loadings ( $(0.4,2.0$ or $4.0 \mathrm{wt} . \%)$ compared to the non-promoted catalyst (MO-0Y).

Fig. 2 shows the $\mathrm{H}_{2}$-TPR of calcined mixed oxides (MO). As demonstrated in other reports, yttrium cannot be reduced under the conditions used in the measurements $[66,67]$. The reduction profile of MO-0Y has two main reduction bands that centered at $366{ }^{\circ} \mathrm{C}$ and $829{ }^{\circ} \mathrm{C}$, which corresponds respectively to the reduction of nickel oxides weakly bonded with the double layered hydroxides and nickel species that are incorporated into the structure of hydroxides $[31,44,63,66,67,75]$. The high-temperature peak shifts towards higher temperatures for all Y-promoted catalysts (Table 3, 858-866 ${ }^{\circ} \mathrm{C}$ ), which indicates stronger interaction between nickel oxide 
species and the support matrix in comparison with Y-free sample [44]. For 2.0 and 4.0 wt.\% of Y, the shift of latter peak was less pronounced, as shown in Table 3, indicating less strong metal-support interaction. This might be due to the segregation of yttrium or lattice substitution of nickel species by yttrium [66]. The reduction peaks at temperatures lower than $600{ }^{\circ} \mathrm{C}$ presented low intensity for Y-modified samples in comparison to the unpromoted catalyst (MO-OY), which means that the loading of $\mathrm{Y}$ results in a decreased reducibility. This phenomenon was already observed in hydrotalcite derived mixed oxides catalysts modified by $\mathrm{Y}$ and $\mathrm{Zr}$ in $\mathrm{CO}_{2}$ dry reforming reaction, in which the adding of $\mathrm{Y}$ and $\mathrm{Zr}$ resulted in a decrease of the reducibility of nickel $[31,44]$. As calculated in Table 3, the highest $\mathrm{H}_{2}$ consumption (1.67 mmol) was obtained for the Y-free mixed-oxide sample. After the introduction of yttrium, the $\mathrm{H}_{2}$ consumptions (1.15-1.38 mmol) of yttrium-promoted mixed oxides decreased in contrast to the yttrium-free sample, demonstrating decreased reducibility of $\mathrm{NiO}$ for yttrium-promoted mixed oxides.

Table $3 \mathrm{H}_{2}$ consumption according to $\mathrm{H}_{2}$-TPR analyses

\begin{tabular}{ccccccc}
\hline Catalyst & \multicolumn{2}{c}{ Temperature $\left({ }^{\circ} \mathrm{C}\right)$} & & \multicolumn{2}{c}{$\mathrm{H}_{2}$ consumption $\left(\mathrm{mmolH}_{2} / \mathrm{g}\right)$} \\
\cline { 2 - 3 } \cline { 5 - 7 } \cline { 5 - 6 } & $<600$ & $>600$ & & $<600$ & $>600$ & Total \\
\hline MO-0Y & 386 & 829 & & 0.37 & 1.30 & 1.67 \\
MO-0.4Y & 320 & 866 & & 0.07 & 1.09 & 1.16 \\
MO-2.0Y & 327 & 858 & & 0.11 & 1.27 & 1.38 \\
MO-4.0Y & 444 & 858 & & 0.05 & 1.10 & 1.15 \\
\hline
\end{tabular}




\subsubsection{Basicity of the catalysts derived from $\mathrm{CO}_{2}$-TPD}

Fig. 3 shows the $\mathrm{CO}_{2}$-TPD profiles of the reduced MO catalysts. Three types of $\mathrm{CO}_{2}$ desorption peaks could be observed with a maximum temperature of 138, 203 and $364{ }^{\circ} \mathrm{C}$ for MO-0Y sample, which refers to weak, medium (intermediate) and strong basic sites, respectively [33,43,44,54]. Similar peaks were found for yttrium-promoted mixed oxides materials, with the maximum temperature of $\mathrm{CO}_{2}$ desorption peak shifted towards lower temperature with the increasing yttrium content compared to the MO-0Y sample, indicating that the loading of $\mathrm{Y}$ changed the number and distribution of the basic sites. This phenomenon was also observed in other literature [44].

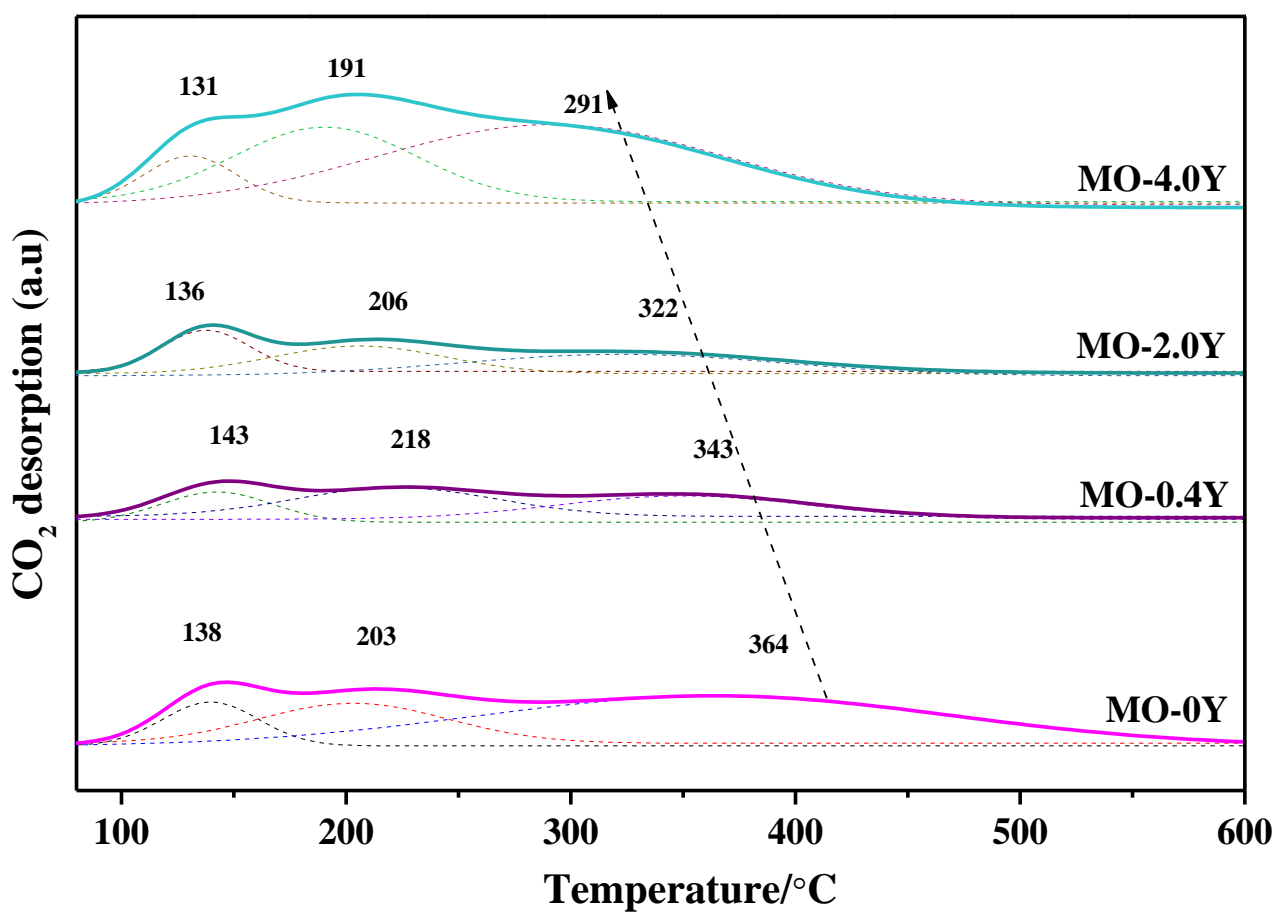

Fig. 3. $\mathrm{CO}_{2}$-TPD profiles for mixed oxides catalysts

As calculated in Table 4, the amount of different type of basic sites for the 
Y-modified samples increased with the increase of yttrium loading (from 0.4 to 4.0 wt $\%)$ and the total number of basic sites also increased with the increased Y content, with MO-4.0Y having the highest number of each type of basic sites as well as the total basic sites. Compared to the basicity of MO-0Y sample, the materials with 0.4 wt.\% and 2.0 wt.\% of Y showed lower content of total basic sites and individual type of basic sites (weak, medium or strong). But compared to that of the MO-0Y, the percentage share of weak or intermediate basic sites for MO-0.4Y and MO-2.0Y was higher, with lower content of the share of strong basic sites, meaning that the doping of yttrium significantly changed the distribution of basic sites on Y-modified samples. In conclude, the introduction of $\mathrm{Y}$ with low content $(0.4 \mathrm{wt} . \%$ and $2.0 \mathrm{wt} . \%)$ results in the increase of share of medium basic sites as the expense of strong type. The highest share of medium-strength basic sites was found on the MO-0.4Y sample.

Table 4 Basicity of the studied catalysts, calculated from $\mathrm{TPD}-\mathrm{CO}_{2}$ for the reduced materials.

\begin{tabular}{lccccccccc}
\hline Catalyst & \multicolumn{4}{c}{ Basic sites $[\mu \mathrm{mol} / \mathrm{g}]$} & & \multicolumn{3}{c}{ Basic sites distribution [\%] } \\
\cline { 2 - 4 } \cline { 8 - 10 } & Weak & Medium & Strong & Total basicity & & Weak & Medium & Strong \\
\hline MO-0Y & 16.4 & 43.9 & 46.3 & 106.6 & & 15.4 & 41.2 & 43.4 \\
MO-0.4Y & 9.4 & 33.7 & 14.6 & 57.7 & & 16.2 & 58.5 & 25.3 \\
MO-2.0Y & 11.6 & 35.2 & 26.4 & 73.2 & & 15.8 & 48.1 & 36.1 \\
MO-4.0Y & 41.4 & 91.5 & 91.2 & 224.1 & & 18.5 & 40.8 & 40.7 \\
\hline
\end{tabular}

\subsection{Catalytic performance tests for $\mathrm{CO}_{2}$ methanation}


Fig. 4 presents the $\mathrm{CO}_{2}$ conversion and Fig.5 presents the methane selectivity measured during catalytic experiments for the studied mixed oxides (MO) promoted with different amounts of $\mathrm{Y}$ as a function of reaction temperature.

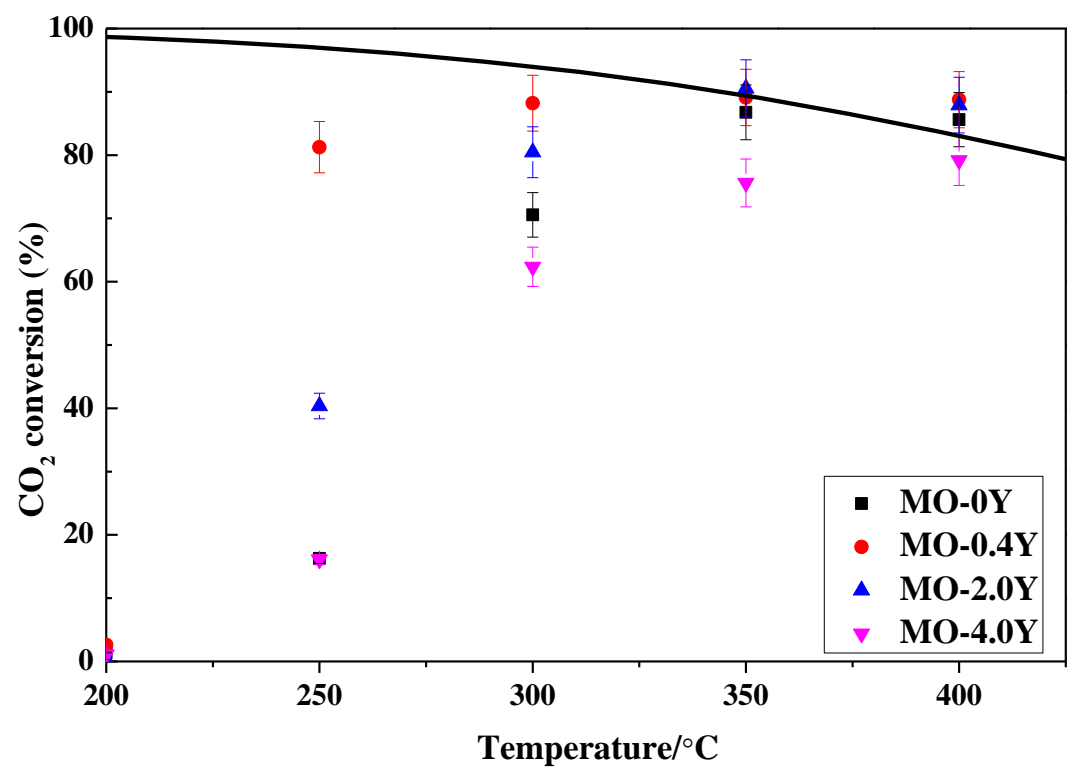

Fig. 4. $\mathrm{CO}_{2}$ conversion of the studied mixed oxides catalysts (MO-0Y, MO-0.4Y, MO-2.0Y, MO-4.0Y). Experimental conditions of $\mathrm{CO}_{2}$ methanation: $\mathrm{GHSV}=12000 \mathrm{~h}^{-1}$, total flow 100 $\mathrm{mL} / \mathrm{min}, \mathrm{CO}_{2} / \mathrm{H}_{2} / \mathrm{Ar}=15 / 60 / 25$.

The thick continuous line shown in Fig. 4 represents the thermodynamic equilibrium calculated for the conditions used in this work [33,54]. According to thermodynamics, $\mathrm{CO}_{2}$ methanation is favored at low temperatures and it decreases with the increasing temperature due to the co-existence of parallel reactions, such as reverse water-gas shift (RWGS) or reforming $[33,76]$. The latter results in undesired side products, among them carbon monoxide [59]. All mixed oxides were catalytically active in $\mathrm{CO}_{2}$ methanation. The obtained conversions at $250{ }^{\circ} \mathrm{C}$ were much lower than the thermodynamic limitations, except for the MO-0.4Y catalyst. Depending on the Y-loading a change in the catalytic performance of the catalysts was observed. 
Nevertheless, the increase of the catalytic conversion was not directly correlated to the increase of yttrium loading. For both series of results registered at $250{ }^{\circ} \mathrm{C}$ and $300{ }^{\circ} \mathrm{C}$, the sequence for the $\mathrm{CO}_{2}$ conversion was: $\mathrm{MO}-0.4 \mathrm{Y}>\mathrm{MO}-2.0 \mathrm{Y}>\mathrm{MO}-0 \mathrm{Y}>$ MO-4.0Y. $\mathrm{CO}_{2}$ conversion increased at $250{ }^{\circ} \mathrm{C}$ from $16 \%$ for $\mathrm{MO}-0 \mathrm{Y}$ to $40 \%$ and $81 \%$ for MO-2.0Y and MO- $0.4 \mathrm{Y}$, respectively, and at $300^{\circ} \mathrm{C}$, from $71 \%$ for MO-0Y to $80 \%$ and $88 \%$ for MO-2.0Y and MO- $0.4 \mathrm{Y}$, respectively. At both temperatures, $250{ }^{\circ} \mathrm{C}$ and $300{ }^{\circ} \mathrm{C}$, the selectivity towards methane was higher than $98.5 \%$, with very low differences between the Y-promoted catalysts (Fig.5). However, in the tested temperature range, both the $\mathrm{CO}_{2}$ conversion and $\mathrm{CH}_{4}$ selectivity for $\mathrm{MO}-4.0 \mathrm{Y}$ decreased in comparison to MO-0Y. This could have been caused by the deposition of the yttrium on the external surface of the support matrix and the weaker metal-support interaction, as confirmed by XRD and TPR- $\mathrm{H}_{2}$.

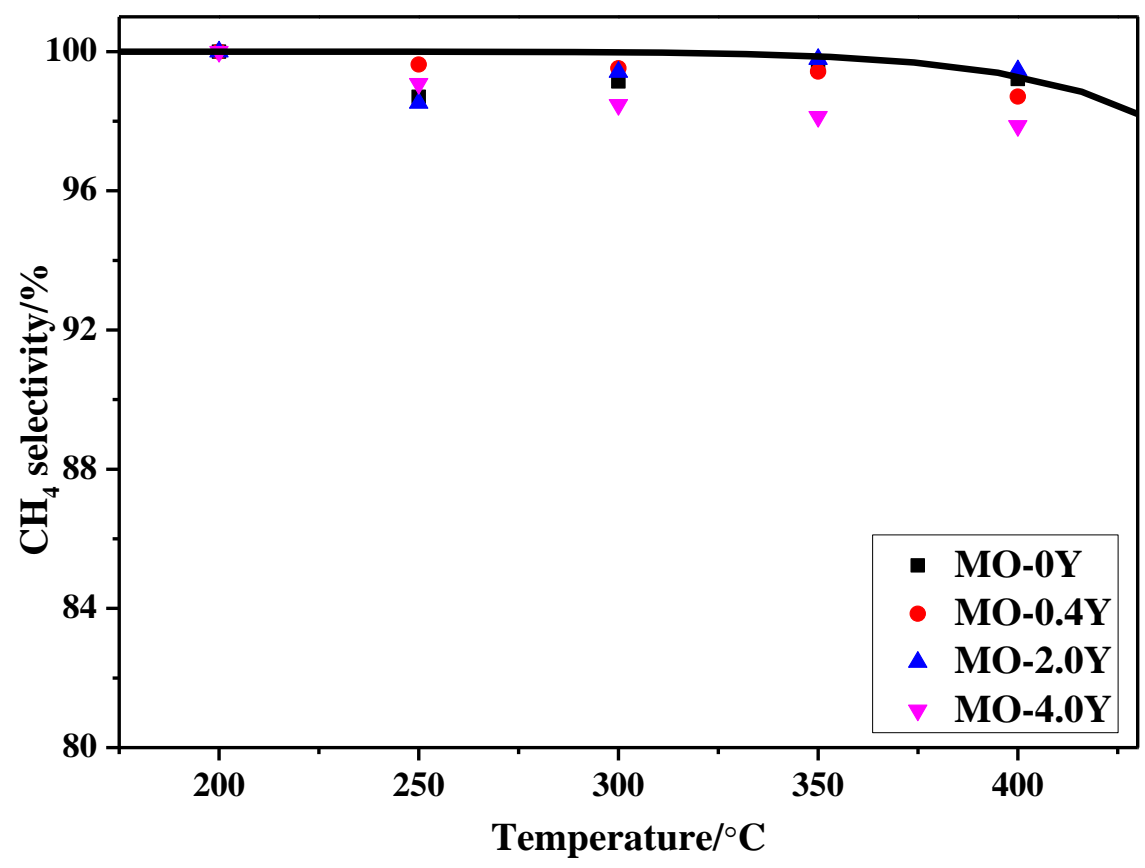

Fig. 5. $\mathrm{CH}_{4}$ selectivity of the studied mixed oxides catalysts (MO-0Y, MO-0.4Y, MO-2.0Y, 
MO-4.0Y). Experimental conditions of $\mathrm{CO}_{2}$ methanation: $\mathrm{GHSV}=12000 \mathrm{~h}^{-1}$, total flow 100 $\mathrm{ml} / \mathrm{min}, \mathrm{CO}_{2} / \mathrm{H}_{2} / \mathrm{Ar}=15 / 60 / 25$.

The enhancement of the activity of Y-promoted catalysts except MO-4.0Y can be partially explained by the smaller $\mathrm{Ni}^{0}$ crystallite size in comparison to the non-promoted sample, which is also found for La-promoted Ni-containing hydrotalcite-derived mixed oxides in $\mathrm{CO}_{2}$ methanation [46].

Simultaneously, the MO-0.4Y catalyst showed the highest percentage share of intermediate-strength basic sites. Pan et al. [77] claimed that Lewis acid-base sites are involved in the $\mathrm{CO}_{2}$ methanation mechanism and the $\mathrm{CO}_{2}$ adsorbed on strong basic sites did not participate in the reaction and the medium-strength basic sites played an important role in the reaction. In the current study, a linear correlation between $\mathrm{CO}_{2}$ conversion and percentage share of medium-strength basic sites can be drawn at $250{ }^{\circ} \mathrm{C}$ and $300{ }^{\circ} \mathrm{C}$ (Fig. 6). It shows that the $\mathrm{CO}_{2}$ conversion increase as the increase of the percentage share of medium-strength basic sites. 


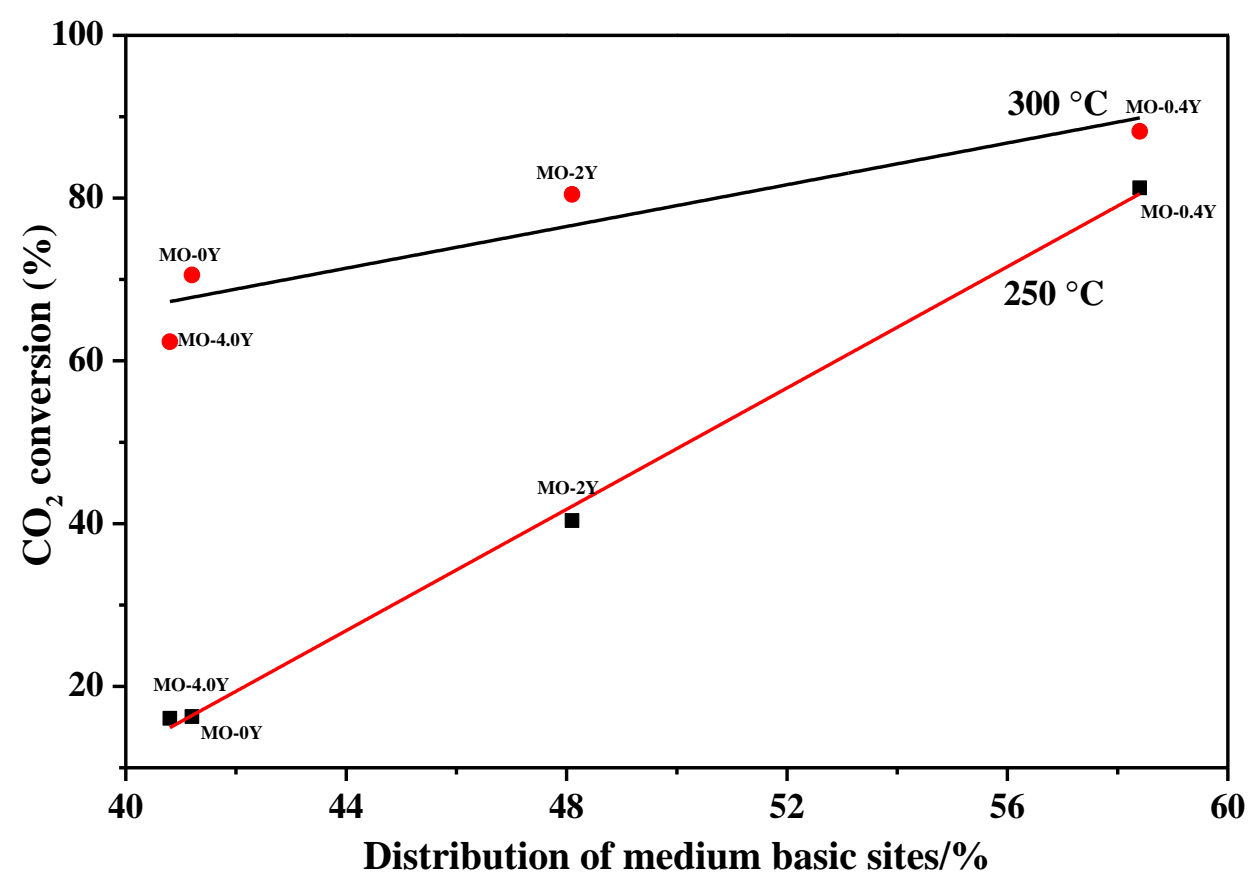

Fig. 6. $\mathrm{CO}_{2}$ conversion at $250{ }^{\circ} \mathrm{C}$ and $300{ }^{\circ} \mathrm{C}$ versus percentage share of medium basic sites of tested catalysts, the black points represent $\mathrm{CO}_{2}$ conversion at $250{ }^{\circ} \mathrm{C}$ and the red points represent $\mathrm{CO}_{2}$ conversion at $300{ }^{\circ} \mathrm{C}$

The medium-strength basic sites play a significant role in the methanation process. Wierzbicki et al. [49,59] found that there was a good linear correlation between the number of medium-strength basic sites and the $\mathrm{CO}_{2}$ conversion on the unpromoted and La-promoted LDHs catalysts. This work confirms that the percentage of medium-strength basic sites have a considerable influence in the case of carbon dioxide methanation on Ni-containing Y-modified mixed oxides catalysts.

Besides, the TPR results show that MO-0.4Y has the highest intensity of metal-support interaction compared to that of other samples [78]. In conclude, the decreased nickel particle size, increased share of medium-strength basic sites and stronger metal-support interactions found for MO-0.4Y catalyst greatly contributed to the enhanced catalytic activity in $\mathrm{CO}_{2}$ methanation. 


\subsection{Characterization of the spent catalysts}

\subsubsection{XRD patterns of the spent samples}

$\mathrm{Ni}^{0}$ crystallite sizes calculated for the spent catalysts are reported in Table 2 . A decrease of the crystallite size was found for the spent catalysts compared to that of the reduced samples, in agreement with Świrk et al. [44] and Dębek et al. [31] on similar materials for other $\mathrm{CO}_{2}$ reactions. This can be explained by the loss of crystallinity of the Ni phase due to its possible re-dispersion of nickel particles. The decreased crystallite size of $\mathrm{Ni}^{0}$ species also indicates that no sintering happened during reaction.

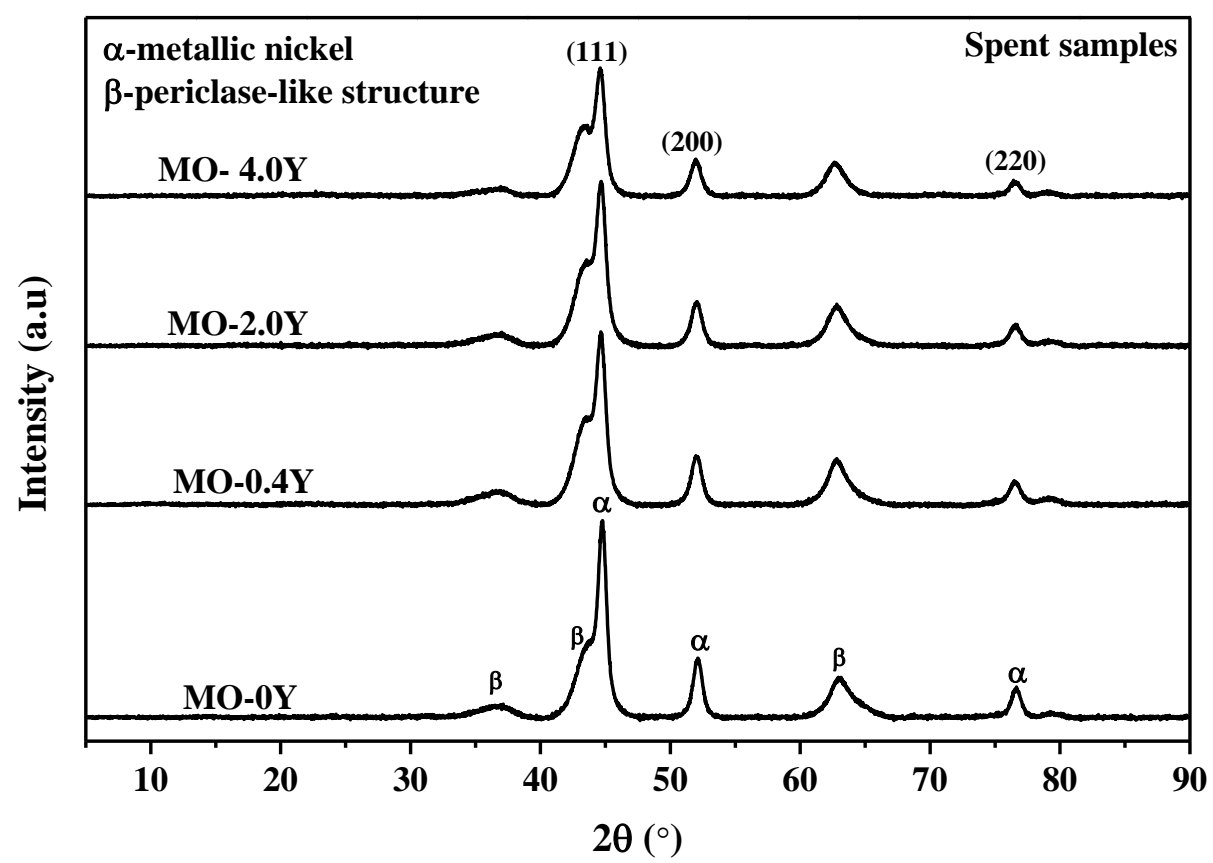

Fig. 7. XRD diffractograms of spent $Y$ modified mixed oxides $(0.4,2.0$, or $4.0 \mathrm{wt} . \%)$ as compared to the unpromoted catalyst (MO-0Y).

After the methanation tests, no reflections corresponding to graphitic carbon (at $2 \theta=27^{\circ}$ ) were observed in the diffractograms of the spent catalysts (Fig. 7). Thus, extensive coking with graphite formation may be excluded. This is in agreement with 
the studies of other authors e.g. Wierzbicki et al. [49], who confirmed the absence of carbon deposition on Ni/Al LDHs-like catalysts for $\mathrm{CO}_{2}$ methanation.

\subsubsection{TGA and TPO tests of the spent samples}

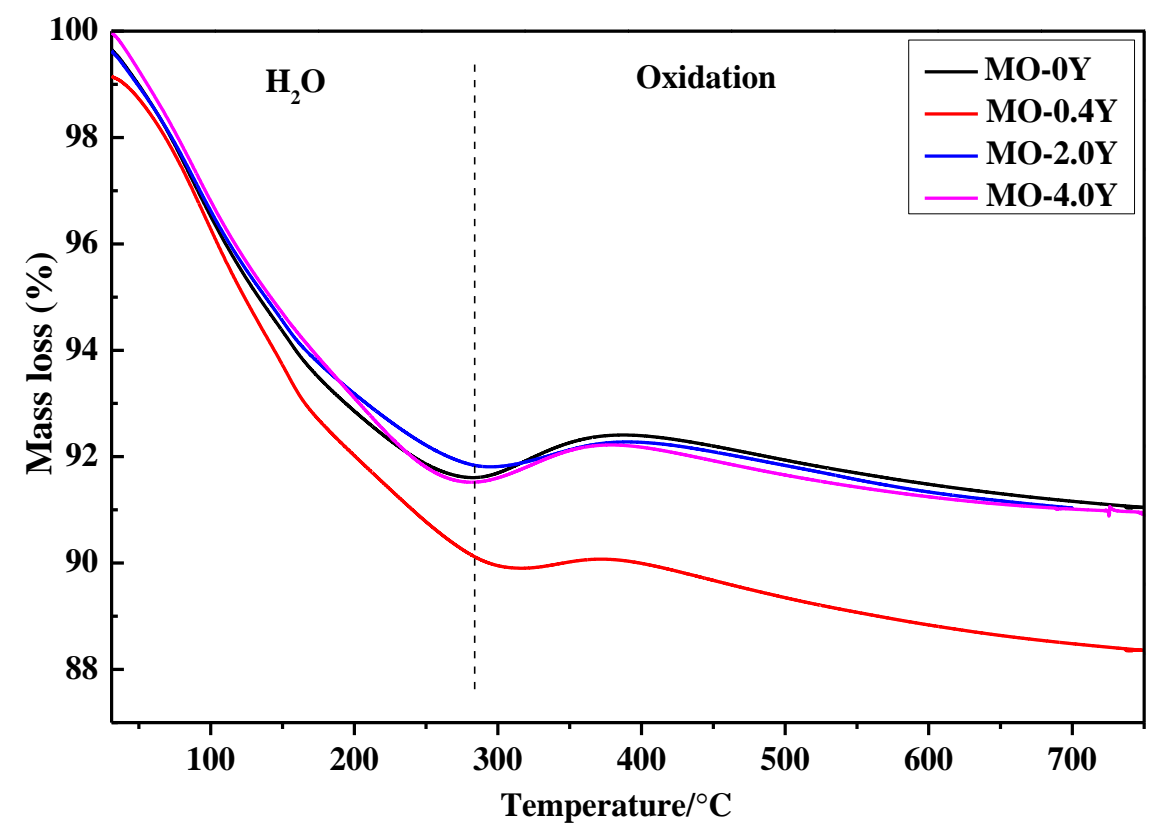

Fig. 8. TGA plots of the studied catalysts (MO-Y0, MO-Y0.4, MO-Y2.0, MO-Y4.0) tested in the methanation process.

Thermogravimetric analyses were carried out for the spent catalysts in order to verify if other non-crystalline carbon species may have been formed (Fig. 8). From Fig.8, two mass loss regions can be observed for all tested MO samples, corresponding respectively to the removal of physically adsorbed water $\left(<250^{\circ} \mathrm{C}\right)$ and a higher temperature region $\left(>400^{\circ} \mathrm{C}\right)$ corresponding to oxidation of metallic nickel to nickel oxide and the removal of residues. From TGA, one can conclude that no significant amount of carbonaceous species was present on the surface of the spent 
catalysts. To confirm this, temperature-programmed oxidation tests were performed from RT to $650{ }^{\circ} \mathrm{C}$ on MO-0Y (Fig. 9a) and MO-0.4Y catalysts (Fig. 9b).

(a)
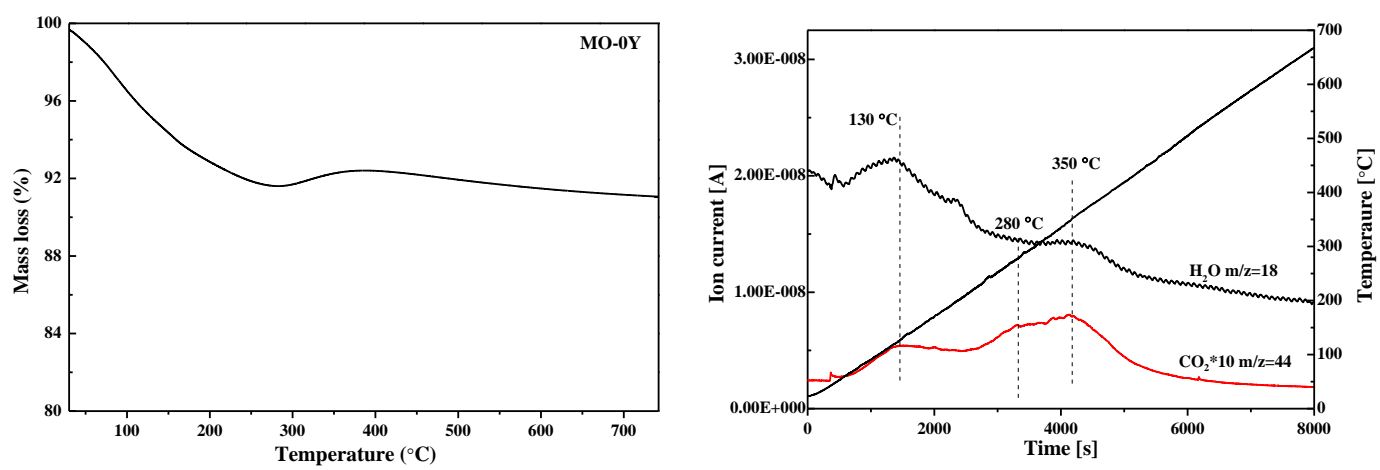

(b)
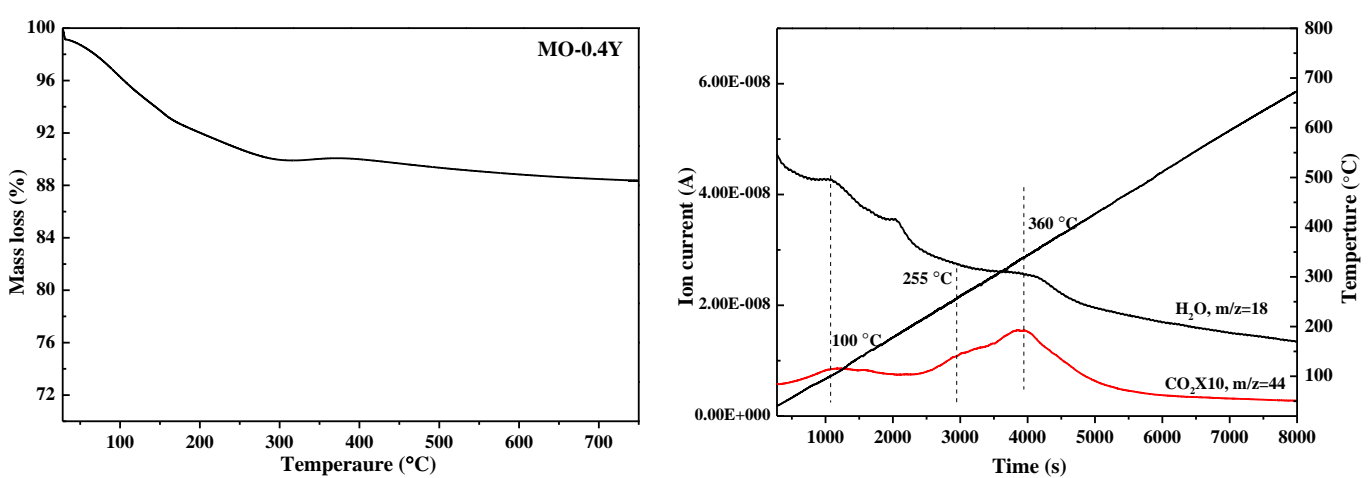

Fig. 9. Temperature-Programmed Oxidation results followed by mass spectroscopy $\left(\mathrm{H}_{2} \mathrm{O} \mathrm{m} / \mathrm{z}=18\right.$ and $\left.\mathrm{CO}_{2} \mathrm{~m} / \mathrm{z}=44 \times 10\right)$ on catalysts; a) unpromoted MO catalysts, b) MO-0.4Y.

From Fig.9a and b, one can observe that $\mathrm{CO}_{2}$ formation corresponding to the decomposition of carbonaceous species $\left(250-500^{\circ} \mathrm{C}\right)$ is very low, confirming 
insignificant amounts of the formed carbonaceous species during the $\mathrm{CO}_{2}$ methanation reaction on the Y promoted catalysts. Thus, the main byproduct in the reaction is $\mathrm{CO}$.

\section{Conclusions}

Yttrium-promoted $\mathrm{Ni} / \mathrm{Mg} / \mathrm{Al}$ hydrotalcite-derived catalysts were synthesized using the co-precipitation method at constant $\mathrm{pH}$. Then, the catalysts were characterized by low-temperature $\mathrm{N}_{2}$ sorption, X-ray diffraction, elemental analysis, and temperature-programmed reduction/desorption $\left(\mathrm{H}_{2}-\mathrm{TPR}\right.$ and $\left.\mathrm{CO}_{2}-\mathrm{TPD}\right)$, and tested as catalysts in $\mathrm{CO}_{2}$ methanation at GHSV $=12000 \mathrm{~h}^{-1}$ using a mixture of $\mathrm{CO}_{2} / \mathrm{H}_{2} / \mathrm{Ar}=15 / 60 / 25$.

The addition of $\mathrm{Y}$ affected the $\mathrm{CO}_{2}$ adsorption capacity of the materials by changing the distribution of the basic sites, especially those of medium-strength. As proven by $\mathrm{H}_{2}$-TPR, the yttrium promotion influenced the nickel/support interaction. After the introduction of yttrium, a shift of reduction peak towards higher temperatures was observed, which was attributed to the segregation of $\mathrm{Y}$ on the support. The $\mathrm{Y}$ addition affected strongly the catalytic activity in $\mathrm{CO}_{2}$ methanation, increasing the $\mathrm{CO}_{2}$ conversion at $250{ }^{\circ} \mathrm{C}$ from $16 \%$ for MO-0Y to 40 and $81 \%$ for MO-2.0Y and MO-0.4Y, respectively. This could be explained by both increased distribution of medium-strength basic sites and significantly smaller metallic nickel particle size of Y-promoted catalysts. Additionally, the metallic nickel crystallite size decreased after the reaction, which points to the reorganization of $\mathrm{Ni}$ at the surface of 
the support, which could contribute to the increase of the catalytic activity in the moderate temperature region. The selectivity towards methane formation was found around 98 to $99 \%$ at $250^{\circ} \mathrm{C}$. It is worth noting that the only products of the reaction registered were $\mathrm{H}_{2} \mathrm{O}, \mathrm{CH}_{4}$ and $\mathrm{CO}$. The XRD, TGA, and TPO analyses confirmed only traces of carbon in the spent catalysts.

\section{Acknowledgments}

Chao Sun would like to express his gratitude for the financial support of CSC (China Scholarship Council) for his Ph.D. research in Sorbonne Université. Katarzyna Świrk would like to acknowledge Prof. Magnus Rønning for the possibility to carry out the elemental analysis and low-temperature $\mathrm{N}_{2}$ sorption at NTNU in Trondheim. Prof. Konrad Świerczek and Anna Olszewska are gratefully acknowledged for thermogravimetric analysis performed at AGH in Cracow.

\section{Reference}

[1] Aresta M, Dibenedetto A, Angelini A. Catalysis for the valorization of exhaust carbon: From $\mathrm{CO} 2$ to chemicals, materials, and fuels. technological use of $\mathrm{CO}_{2}$. Chem Rev 2014;114:1709-42. doi:10.1021/cr4002758.

[2] Wang W, Gong J. Methanation of carbon dioxide: An overview. Front. Chem. Sci. Eng. 2011;5:2-10. doi:10.1007/s11705-010-0528-3.

[3] Guilera J, Del Valle J, Alarcón A, Díaz JA, Andreu T. Metal-oxide promoted $\mathrm{Ni} / \mathrm{Al}_{2} \mathrm{O}_{3}$ as $\mathrm{CO}_{2}$ methanation micro-size catalysts. J CO2 Util 2019;30:11-7. doi:10.1016/j.jcou.2019.01.003.

[4] Götz M, Lefebvre J, Mörs F, McDaniel Koch A, Graf F, Bajohr S, et al. Renewable Power-to-Gas: A technological and economic review. Renew Energy 2016;85:1371-90. doi:10.1016/j.renene.2015.07.066.

[5] Zağli E, Falconer JL. Carbon dioxide adsorption and methanation on Ruthenium. J Catal 1981;69:1-8.

[6] Li M, Amari $\mathrm{H}$, van Veen AC. Metal-oxide interaction enhanced $\mathrm{CO}_{2}$ activation 
in methanation over ceria supported nickel nanocrystallites. Appl Catal B Environ 2018;239:27-35. doi:10.1016/j.apcatb.2018.07.074.

[7] Aziz MAA, Jalil AA, Triwahyono S, Ahmad A. $\mathrm{CO}_{2}$ methanation over heterogeneous catalysts: Recent progress and future prospects. Green Chem 2015;17:2647-63. doi:10.1039/c5gc00119f.

[8] Zhang W, Yang S, Li J, Gao W, Deng Y, Dong W, et al. Visible-to-ultraviolet Upconvertion: Energy transfer, material matrix, and synthesis strategies. Appl Catal B Environ 2017;206:89-103. doi:10.1016/j.apcatb.2017.01.023.

[9] Zhen W, Gao F, Tian B, Ding P, Deng Y, Li Z, et al. Enhancing activity for carbon dioxide methanation by encapsulating (1 111 ) facet $\mathrm{Ni}$ particle in metal-organic frameworks at low temperature. J Catal 2017;348:200-11. doi:10.1016/j.jcat.2017.02.031.

[10] Panagiotopoulou P, Kondarides DI, Verykios XE. Selective methanation of CO over supported noble metal catalysts: Effects of the nature of the metallic phase on catalytic performance. Appl Catal A Gen 2008;344:45-54.

[11] Yaccato K, Carhart R, Hagemeyer A, Lesik A, Strasser P, Volpe AF, et al. Competitive $\mathrm{CO}$ and $\mathrm{CO}_{2}$ methanation over supported noble metal catalysts in high throughput scanning mass spectrometer. Appl Catal A Gen 2005;296:30-48. doi:10.1016/j.apcata.2005.07.052.

[12] Frontera P, Macario A, Ferraro M, Antonucci P. Supported Catalysts for $\mathrm{CO}_{2}$ Methanation: A Review. Catalysts 2017;7:59. doi:10.3390/catal7020059.

[13] Kruatim J, Jantasee S, Jongsomjit B. Improvement of cobalt dispersion on Co/SBA-15 and Co/SBA-16 catalysts by ultrasound and vacuum treatments during Post-impregnation step. Eng J 2017;21:17-28. doi:10.4186/ej.2017.21.1.17.

[14] Czuma N, Zarębska K, Motak M, Gálvez ME, Da Costa P. Ni/zeolite X derived from fly ash as catalysts for $\mathrm{CO}_{2}$ methanation. Fuel 2020;267. doi:10.1016/j.fuel.2020.117139.

[15] Tada S, Ochieng OJ, Kikuchi R, Haneda T, Kameyama H. Promotion of $\mathrm{CO}_{2}$ methanation activity and $\mathrm{CH}_{4}$ selectivity at low temperatures over $\mathrm{Ru} / \mathrm{CeO}_{2} / \mathrm{Al}_{2} \mathrm{O}_{3}$ catalysts. Int $\mathrm{J}$ Hydrogen Energy 2014;39:10090-100. doi:10.1016/j.ijhydene.2014.04.133.

[16] Liu Q, Bian B, Fan J, Yang J. Cobalt doped Ni based ordered mesoporous catalysts for $\mathrm{CO}_{2}$ methanation with enhanced catalytic performance. Int J Hydrogen Energy 2018;43:4893-901. doi:10.1016/j.ijhydene.2018.01.132.

[17] Liang $\mathrm{C}, \mathrm{Hu} \mathrm{X}$, Wei T, Jia P, Zhang Z. Methanation of $\mathrm{CO}_{2}$ over $\mathrm{Ni} / \mathrm{Al}_{2} \mathrm{O}_{3}$ modified with alkaline earth metals : Impacts of oxygen vacancies on catalytic activity. Int J Hydrogen Energy 2019;44:8197-213. doi:10.1016/j.ijhydene.2019.02.014.

[18] Fatah NAA, Jalil AA, Rahman AFA, Hambali HU, Hussain I. $\mathrm{CO}_{2}$ Methanation over Mesoporous Silica Based Catalyst : A Comprehensive Study. J Energy Saf Technol 2019;02:49-53.

[19] Beuls A, Swalus C, Jacquemin M, Heyen G, Karelovic A, Ruiz P. Methanation of $\mathrm{CO} 2$ : Further insight into the mechanism over $\mathrm{Rh} / \gamma-\mathrm{Al}_{2} \mathrm{O}_{3}$ catalyst. Appl 
Catal B Environ 2012;113-114:2-10. doi:10.1016/j.apcatb.2011.02.033.

[20] Shin HH, Lu L, Yang Z, Kiely CJ, McIntosh S. Cobalt Catalysts Decorated with Platinum Atoms Supported on Barium Zirconate Provide Enhanced Activity and Selectivity for $\mathrm{CO}_{2}$ Methanation. ACS Catal 2016;6:2811-8. doi:10.1021/acscatal.6b00005.

[21] Beaumont SK, Alayoglu S, Specht C, Michalak WD, Pushkarev V V., Guo J, et al. Combining in situ NEXAFS spectroscopy and $\mathrm{CO}_{2}$ methanation kinetics to study $\mathrm{Pt}$ and $\mathrm{Co}$ nanoparticle catalysts reveals key insights into the role of platinum in promoted cobalt catalysis. J Am Chem Soc 2014;136:9898-901. doi:10.1021/ja505286j.

[22] Panagiotopoulou P. Hydrogenation of $\mathrm{CO}_{2}$ over supported noble metal catalysts. Appl Catal A Gen 2017;542:63-70.

[23] Ignacio Iglesias, Adrian Quindimil, Fernando Marino, Unai De-La-Torre JRG-V. $\mathrm{Zr}$ promotion effect in $\mathrm{CO}_{2}$ methanation over ceria supported nickel catalysts. Int J Hydrogen Energy 2019;44:1710-9. doi:10.1016/j.ijhydene.2018.11.059.

[24] Vrijburg WL, Garbarino G, Chen W, Parastaev A, Longo A, Pidko EA, et al. $\mathrm{Ni}-\mathrm{Mn}$ catalysts on silica-modified alumina for $\mathrm{CO}_{2}$ methanation. J Catal 2020;382:358-71. doi:10.1016/j.jcat.2019.12.026.

[25] Yatagai K, Shishido Y, Gemma R, Boll T, Uchida HH, Oguri K. Mechanochemical $\mathrm{CO}_{2}$ methanation over LaNi-based alloys. Int J Hydrogen Energy 2020;45:5264-75. doi:10.1016/j.ijhydene.2019.07.055.

[26] Everett OE, Zonetti PC, Alves OC, de Avillez RR, Appel LG. The role of oxygen vacancies in the $\mathrm{CO}_{2}$ methanation employing $\mathrm{Ni} / \mathrm{ZrO}_{2}$ doped with $\mathrm{Ca}$. Int J Hydrogen Energy 2020;45:6352-9. doi:10.1016/j.ijhydene.2019.12.140.

[27] Zhang T, Liu Q. Mesostructured cellular foam silica supported bimetallic $\mathrm{LaNi}_{1-\mathrm{x}} \mathrm{Co}_{\mathrm{x}} \mathrm{O}_{3}$ catalyst for $\mathrm{CO}_{2}$ methanation. Int $\mathrm{J}$ Hydrogen Energy 2020;45:4417-26. doi:10.1016/j.ijhydene.2019.12.006.

[28] Liang C, Tian H, Gao G, Zhang S, Liu Q, Dong D, et al. Methanation of $\mathrm{CO}_{2}$ over alumina supported nickel or cobalt catalysts: Effects of the coordination between metal and support on formation of the reaction intermediates. Int $\mathbf{J}$ Hydrogen Energy 2020;45:531-43. doi:10.1016/j.ijhydene.2019.10.195.

[29] F. Cavani, F. Trifirò AV. Hydrotalcite-type anionic clays: Preparation, properties and applications. Catal Today 1991;11:173-301.

[30] Liu J, Bing W, Xue X, Wang F, Wang B, He S, et al. Alkaline-assisted Ni nanocatalysts with largely enhanced low-temperature activity toward $\mathrm{CO}_{2}$ methanation. Catal Sci Technol 2016;6:3976-83. doi:10.1039/c5cy02026c.

[31] Dębek R, Motak M, Galvez ME, Grzybek T, Da Costa P. Promotion effect of zirconia on $\mathrm{Mg}(\mathrm{Ni}, \mathrm{Al}) \mathrm{O}$ mixed oxides derived from hydrotalcites in $\mathrm{CO}_{2}$ methane reforming. Appl Catal B Environ 2018;223:36-46. doi:10.1016/j.apcatb.2017.06.024.

[32] Dębek R, Motak M, Galvez ME, Grzybek T, Da Costa P. Influence of Ce/Zr molar ratio on catalytic performance of hydrotalcite-derived catalysts at low temperature $\mathrm{CO}_{2}$ methane reforming. Int $\mathrm{J}$ Hydrogen Energy 
2017;42:23556-67. doi:10.1016/j.ijhydene.2016.12.121.

[33] Liu H, Wierzbicki D, Debek R, Motak M, Grzybek T, Da Costa P, et al. La-promoted Ni-hydrotalcite-derived catalysts for dry reforming of methane at low temperatures. Fuel 2016;182:8-16. doi:10.1016/j.fuel.2016.05.073.

[34] Dębek R, Radlik M, Motak M, Galvez ME, Turek W, Da Costa P, et al. $\mathrm{Ni}$-containing Ce-promoted hydrotalcite derived materials as catalysts for methane reforming with carbon dioxide at low temperature - On the effect of basicity. Catal Today 2015;257:59-65. doi:10.1016/j.cattod.2015.03.017.

[35] Wierzbicki D, Dębek R, Szczurowski J, Basąg S, Włodarczyk M, Motak M, et al. Copper, cobalt and manganese: Modified hydrotalcite materials as catalysts for the selective catalytic reduction of NO with ammonia. the influence of manganese concentration. Comptes Rendus Chim 2015;18:1074-83.

[36] Chmielarz L, Kuśtrowski P, Rafalska-Łasocha A, Majda D, Dziembaj R. Catalytic activity of $\mathrm{Co}-\mathrm{Mg}-\mathrm{Al}, \mathrm{Cu}-\mathrm{Mg}-\mathrm{Al}$ and $\mathrm{Cu}-\mathrm{Co}-\mathrm{Mg}-\mathrm{Al}$ mixed oxides derived from hydrotalcites in SCR of NO with ammonia. Appl Catal B Environ 2002;35:195-210. doi:10.1016/S0926-3373(01)00254-5.

[37] Carja G, Delahay G. Mesoporous mixed oxides derived from pillared oxovanadates layered double hydroxides as new catalysts for the selective catalytic reduction of $\mathrm{NO}$ by $\mathrm{NH}_{3}$. Appl Catal B Environ 2004;47:59-66. doi:10.1016/j.apcatb.2003.07.004.

[38] Wu X, Feng Y, Du Y, Liu X, Zou C, Li Z. Enhancing DeNOx performance of CoMnAl mixed metal oxides in low-temperature $\mathrm{NH}_{3}$-SCR by optimizing layered double hydroxides (LDHs) precursor template. Appl Surf Sci 2019;467-468:802-10. doi:10.1016/j.apsusc.2018.10.191.

[39] Quoc TT, Du SL, Van DP, Khac NN, Dinh LT. Temporary overvoltages in the Vietnam $500 \mathrm{kV}$ transmission line. Proc IEEE Int Conf Transm Distrib Constr Live Line Maintenance, ESMO 1998:225-30. doi:10.1109/tdcllm.1998.668378.

[40] Chai R, Fan S, Zhang Z, Chen P, Zhao G, Liu Y, et al. Free-Standing NiO-MgO- $\mathrm{Al}_{2} \mathrm{O}_{3}$ Nanosheets Derived from Layered Double Hydroxides Grown onto FeCrAl-Fiber as Structured Catalysts for Dry Reforming of Methane. ACS Sustain Chem Eng 2017;5:4517-22. doi:10.1021/acssuschemeng.7b00717.

[41] Zhang X, Yang C, Zhang Y, Xu Y, Shang S, Yin Y. Ni-Co catalyst derived from layered double hydroxides for dry reforming of methane. Int $\mathrm{J}$ Hydrogen Energy 2015;40:16115-26. doi:10.1016/j.ijhydene.2015.09.150.

[42] Tsyganok AI, Tsunoda T, Hamakawa S, Suzuki K, Takehira K, Hayakawa T. Dry reforming of methane over catalysts derived from nickel-containing $\mathrm{Mg}-\mathrm{Al}$ layered double hydroxides. J Catal 2003;213:191-203. doi:10.1016/S0021-9517(02)00047-7.

[43] Dębek R, Radlik M, Motak M, Galvez ME, Turek W, Da Costa P, et al. Ni-containing Ce-promoted hydrotalcite derived materials as catalysts for methane reforming with carbon dioxide at low temperature - On the effect of basicity. Catal Today 2015;257:59-65. doi:10.1016/j.cattod.2015.03.017. 
[44] Świrk K, Gálvez ME, Motak M, Grzybek T, Rønning M, Da Costa P. Yttrium promoted Ni-based double-layered hydroxides for dry methane reforming. J CO2 Util 2018;27:247-58. doi:10.1016/j.jcou.2018.08.004.

[45] Świrk K, Gálvez ME, Motak M, Grzybek T, Rønning M, Da Costa P. Dry reforming of methane over $\mathrm{Zr}$ - and Y-modified $\mathrm{Ni} / \mathrm{Mg} / \mathrm{Al}$ double-layered hydroxides. Catal Commun 2018;117:26-32.

[46] Wierzbicki D, Motak M, Grzybek T, Gálvez ME, Da Costa P. The influence of lanthanum incorporation method on the performance of nickel-containing hydrotalcite-derived catalysts in $\mathrm{CO}_{2}$ methanation reaction. Catal Today 2018;307:205-11. doi:10.1016/j.cattod.2017.04.020.

[47] Świrk K, Motak M, Grzybek T, Rønning M, Da Costa P. Effect of low loading of yttrium on Ni-based layered double hydroxides in $\mathrm{CO}_{2}$ reforming of $\mathrm{CH}_{4}$. React Kinet Mech Catal 2018. doi:10.1007/s11144-018-1515-9.

[48] Wierzbicki D, Baran R, Dębek R, Motak M, Gálvez ME, Grzybek T, et al. Examination of the influence of $\mathrm{La}$ promotion on $\mathrm{Ni}$ state in hydrotalcite-derived catalysts under $\mathrm{CO}_{2}$ methanation reaction conditions: Operando X-ray absorption and emission spectroscopy investigation. Appl Catal B Environ 2018;232:409-19. doi:10.1016/j.apcatb.2018.03.089.

[49] Wierzbicki D, Baran R, Dębek R, Motak M, Grzybek T, Gálvez ME, et al. The influence of nickel content on the performance of hydrotalcite-derived catalysts in $\mathrm{CO}_{2}$ methanation reaction. Int $\mathbf{J}$ Hydrogen Energy 2017;42:23548-55. doi:10.1016/j.ijhydene.2017.02.148.

[50] Wierzbicki D, Debek R, Motak M, Grzybek T, Gálvez ME, Da Costa P. Novel Ni-La-hydrotalcite derived catalysts for $\mathrm{CO}_{2}$ methanation. Catal Commun 2016;83:5-8. doi:10.1016/j.catcom.2016.04.021.

[51] Wierzbicki D, Moreno MV, Ognier S, Motak M, Grzybek T, Da Costa P, et al. $\mathrm{Ni}-\mathrm{Fe}$ layered double hydroxide derived catalysts for non-plasma and DBD plasma-assisted $\mathrm{CO}_{2}$ methanation. Int $\mathrm{J}$ Hydrogen Energy 2019. doi:10.1016/j.ijhydene.2019.06.095.

[52] Zhang Z, Tian Y, Zhang L, Hu S, Xiang J, Wang Y, et al. Impacts of nickel loading on properties, catalytic behaviors of $\mathrm{Ni} /{ }-\mathrm{Al}_{2} \mathrm{O}_{3}$ catalysts and the reaction intermediates formed in methanation of CO2. Int $\mathrm{J}$ Hydrogen Energy 2019;44:9291-306. doi:10.1016/j.ijhydene.2019.02.129.

[53] Zhou J, Ma H, Liu C, Zhang H, Ying W. High temperature methanation over Ni catalysts supported on high surface area $\mathrm{ZnxMg}_{1-\mathrm{x}} \mathrm{Al}_{2} \mathrm{O}_{4}$ : Influence on $\mathrm{Zn}$ loading. Int J Hydrogen Energy 2019;44:13253-61. doi:10.1016/j.ijhydene.2019.03.197.

[54] Wierzbicki D, Baran R, Dębek R, Motak M, Gálvez ME, Grzybek T, et al. Examination of the influence of $\mathrm{La}$ promotion on $\mathrm{Ni}$ state in hydrotalcite-derived catalysts under $\mathrm{CO}_{2}$ methanation reaction conditions: Operando X-ray absorption and emission spectroscopy investigation. Appl Catal B Environ 2018;232:409-19. doi:10.1016/j.apcatb.2018.03.089.

[55] Wang X, Zhen T, Yu C. Application of Ni-Al-hydrotalcite-derived catalyst modified with $\mathrm{Fe}$ or $\mathrm{Mg}$ in $\mathrm{CO}_{2}$ methanation. Appl Petrochemical Res 
2016;6:217-23.

[56] Fan Z, Sun K, Rui N, Zhao B, Liu CJ. Improved activity of $\mathrm{Ni} / \mathrm{MgAl}_{2} \mathrm{O}_{4}$ for $\mathrm{CO} 2$ methanation by the plasma decomposition. J Energy Chem 2015;24:655-9.

[57] Fan Z, Sun K, Rui N, Zhao B, Liu CJ. Improved activity of $\mathrm{Ni} / \mathrm{MgAl}_{2} \mathrm{O}_{4}$ for $\mathrm{CO}_{2}$ methanation by the plasma decomposition. J Energy Chem 2015;24:655-9. doi:10.1016/j.jechem.2015.09.004.

[58] Mebrahtu C, Krebs F, Perathoner S, Abate S, Centi G, Palkovits R. Hydrotalcite based $\mathrm{Ni}-\mathrm{Fe} /(\mathrm{Mg}, \mathrm{Al}) \mathrm{O}_{\mathrm{x}}$ catalysts for $\mathrm{CO}_{2}$ methanation-tailoring Fe content for improved CO dissociation, basicity, and particle size. Catal Sci Technol 2018;8:1016-27.

[59] Wierzbicki D, Motak M, Grzybek T, Gálvez ME, Da Costa P. The influence of lanthanum incorporation method on the performance of nickel-containing hydrotalcite-derived catalysts in $\mathrm{CO}_{2}$ methanation reaction. Catal Today 2018;307:205-11.

[60] Pan Q, Peng J, Sun T, Wang S, Wang S. Insight into the reaction route of $\mathrm{CO}_{2}$ methanation: Promotion effect of medium basic sites. Catal Commun 2014;45:74-8. doi:10.1016/j.catcom.2013.10.034.

[61] J. M. Ferna'ndez, C. Barriga, M. A. Ulibarri, F. M. Labajos and V. Rives. New Hydrotalcite-like Compounds Containing Yttrium. Chem Mater 1997, 1997;9:312-8.

[62] Liu HR, Świrk K, Galvez ME, da Costa P. Nickel Supported Modified Ceria Zirconia Lanthanum/ Praseodymium/Yttrium Oxides Catalysts for Syngas Production through Dry Methane Reforming. Mater Sci Forum 2018;941:2214-9. doi:10.4028/www.scientific.net/msf.941.2214.

[63] Świrk K, Gálvez ME, Motak M, Grzybek T, Rønning M, Da Costa P. Syngas production from dry methane reforming over yttrium-promoted nickel-KIT-6 catalysts. Int J Hydrogen Energy 2018:1-13. doi:10.1016/j.ijhydene.2018.02.164.

[64] Świrk K, Rønning M, Motak M, Beaunier P, Da Costa P, Grzybek T. Ce- and Y-Modified Double-Layered Hydroxides as Catalysts for Dry Reforming of Methane: On the Effect of Yttrium Promotion. Catalysts 2019;9:56. doi:10.3390/catal9010056.

[65] Świrk K, Gálvez ME, Motak M, Grzybek T, Rønning M, Da Costa P. Dry reforming of methane over $\mathrm{Zr}$ - and Y-modified $\mathrm{Ni} / \mathrm{Mg} / \mathrm{Al}$ double-layered hydroxides. Catal Commun 2018;117:26-32. doi:10.1016/j.catcom.2018.08.024.

[66] Li JF, Xia C, Au CT, Liu BS. $\mathrm{Y}_{2} \mathrm{O}_{3}$-promoted NiO/SBA-15 catalysts highly active for CO2/CH4 reforming. Int J Hydrogen Energy 2014;39:10927-40. doi:10.1016/j.ijhydene.2014.05.021.

[67] Bellido JDA, Assaf EM. Effect of the $\mathrm{Y}_{2} \mathrm{O}_{3}-\mathrm{ZrO}_{2}$ support composition on nickel catalyst evaluated in dry reforming of methane. Appl Catal A Gen 2009;352:179-87.

[68] Muroyama H, Tsuda Y, Asakoshi T, Masitah H, Okanishi T, Matsui T, et al. 
Carbon dioxide methanation over $\mathrm{Ni}$ catalysts supported on various metal oxides. J Catal 2016;343:178-84.

[69] García-García JM, Pérez-Bernal ME, Ruano-Casero RJ, Rives V. Chromium and yttrium-doped magnesium aluminum oxides prepared from layered double hydroxides. Solid State Sci 2007;9:1115-25. doi:10.1016/j.solidstatesciences.2007.07.029.

[70] Fernández JM, Barriga C, Ulibarri MA, Labajos FM, Rives V. New Hydrotalcite-like Compounds Containing Yttrium. Chem Mater 1997;9:312-8. doi:10.1021/cm9603720.

[71] Kovanda F, Koloušek D, Cílová Z, Hulínský V. Crystallization of synthetic hydrotalcite under hydrothermal conditions. Appl Clay Sci 2005;28:101-9. doi:10.1016/j.clay.2004.01.009.

[72] Kloprogge JT, Kristóf J, Frost RL. Thermogravimetric analysis-mass spectrometry (TGA-MS) of hydrotalcites containing $\mathrm{CO}_{3}{ }^{2-}, \mathrm{NO}_{3}{ }^{-}, \mathrm{Cl}^{-}, \mathrm{SO}_{4}{ }^{2-}$ or $\mathrm{ClO}_{4}^{-} .2003$.

[73] Cavani F, Trifirò F, Vaccari A. Hydrotalcite-type anionic clays: Preparation, properties and applications. Catal Today 1991;11:173-301. doi:10.1016/0920-5861(91)80068-K.

[74] Dębek R, Galvez ME, Launay F, Motak M, Grzybek T, Da Costa P. Low temperature dry methane reforming over $\mathrm{Ce}, \mathrm{Zr}$ and $\mathrm{CeZr}$ promoted $\mathrm{Ni}-\mathrm{Mg}-\mathrm{Al}$ hydrotalcite-derived catalysts. Int J Hydrogen Energy 2016;41:11616-23. doi:10.1016/j.ijhydene.2016.02.074.

[75] Sánchez EA, D’Angelo MA, Comelli RA. Hydrogen production from glycerol on $\mathrm{Ni} / \mathrm{Al}_{2} \mathrm{O}_{3}$ catalyst. Int $\mathbf{J}$ Hydrogen Energy 2010;35:5902-7. doi:10.1016/j.ijhydene.2009.12.115.

[76] Wang L, Liu H, Liu Y, Chen Y, Yang S. Effect of precipitants on Ni-CeO catalysts prepared by a co-precipitation method for the reverse water-gas shift reaction. J Rare Earths 2013;31:969-74. doi:10.1016/S1002-0721(13)60014-9.

[77] Wang S, Pan Q, Peng J, Sun T, Gao D, Wang S. $\mathrm{CO}_{2}$ methanation on $\mathrm{Ni} / \mathrm{Ce}_{0.5} \mathrm{Zr}_{0.5} \mathrm{O}_{2}$ catalysts for the production of synthetic natural gas. Fuel Process Technol 2014;123:166-71. doi:10.1016/j.fuproc.2014.01.004.

[78] Kumar R, Kumar K, Pant KK, Choudary N V. Tuning the metal-support interaction of methane tri-reforming catalysts for industrial flue gas utilization. Int J Hydrogen Energy 2019;45:1911-29. doi:10.1016/j.ijhydene.2019.11.111. 